Prepared for the U.S. Department of Energy

under Contract DE-AC05-76RL01830

\title{
Utility of Social Modeling for Proliferation Assessment
}

Enhancing a Facility-Level Model for Proliferation Resistance Assessment of a Nuclear Energy System
GA Coles
AJ Brothers
JR Olson
ZN Gastelum
SE Thompson

October 2009

Pacific Northwest

NATIONAL LABORATORY

Proudly Operated by Battelle Since 1965 


\section{DISCLAIMER}

This report was prepared as an account of work sponsored by an agency of the United States Government. Neither the United States Government nor any agency thereof, nor Battelle Memorial Institute, nor any of their employees, makes any warranty, express or implied, or assumes any legal liability or responsibility for the accuracy, completeness, or usefulness of any information, apparatus, product, or process disclosed, or represents that its use would not infringe privately owned rights. Reference herein to any specific commercial product, process, or service by trade name, trademark, manufacturer, or otherwise does not necessarily constitute or imply its endorsement, recommendation, or favoring by the United States Government or any agency thereof, or Battelle Memorial Institute. The views and opinions of authors expressed herein do not necessarily state or reflect those of the United States Government or any agency thereof.

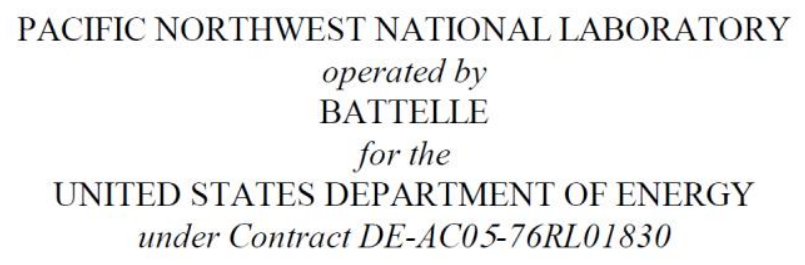

Printed in the United States of America

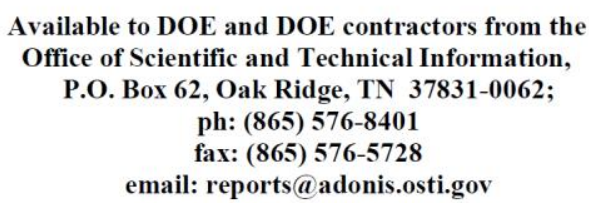

Available to the public from the National Technical Information Service, U.S. Department of Commerce, $\mathbf{5 2 8 5}$ Port Royal Rd., Springfield, VA 22161 ph: (800) 553-6847 fax: (703) 605-6900

email: orders@ntis.fedworld.gov

online ordering: http://www.ntis.gov/ordering.htm

This document was printed on recycled paper. 


\section{Utility of Social Modeling for Proliferation Assessment}

Enhancing a Facility-Level Model for Proliferation Resistance Assessment of a Nuclear Energy System

$\begin{array}{lll}\text { GA Coles } & \text { AJ Brothers } & \text { JR Olson } \\ \text { S Thompson } & \text { ZN Gastelum } & \end{array}$

October 2009

Prepared for

the U.S. Department of Energy

under Contract DE-AC05-76RL01830

Pacific Northwest National Laboratory

Richland, Washington 99352 



\section{Summary}

This report presents the results of efforts towards development of a Facility-Level Model (i.e., singlelocation assessment) that demonstrates the use of social modeling to enhance an assessment process that is technical in nature. This effort builds on a literature search and preliminary assessment performed as the first stage of the Utility of Social Modeling or Proliferation Assessment project. This second report represents the culmination of the first year of research for project PL09-UtilSocial.

This report provides: 1) background information on relevant social factors literature and on existing facility assessment modeling approaches germane to this demonstration, 2) a discussion of social modeling done to support determination of social factors relevant to nuclear facility modeling, 3) an enhancement concept for a specific existing nuclear facility assessment model using social factors, 4) a discussion of engagement with the facility assessment model owners about using social factors, 5) discussion of implementation of the new assessment approach based on the proposed modeling enhancement, including discussion of functionality and potential users, and 6) conclusions. This report represents technical deliverables for the NA-22 Simulations, Algorithms, and Modeling program. Specifically this report is the Task 2 and 3 deliverables for project PL09-UtilSocial.

Based on the literature search preliminary assessment (i.e., PNNL-18438, Utility of Social Modeling for Proliferation Assessment) performed as the first stage of this research, we have concluded that there are opportunities to use social models to improve understanding and assessment of proliferation-related problems. For decades analysts have theorized about the factors that dictate whether a State pursues the development of nuclear weapons-these factors are primarily social factors or are factors that are intimately related to social factors (e.g., national identity, leadership, politics, domestic security, and economic capability). Social modeling offers a way to formalize or leverage this body of analysis and theory. PNNL-18438 also identifies opportunities for social modeling to support both overarching kinds of assessments like a State safeguards evaluation; facility-level assessments like a Proliferation Resistance (PR) assessment of a nuclear energy system (NES); and other kinds of specific proliferation assessmentrelated modeling efforts such as the use of satellite imagery to identify proliferation activity.

One kind of facility-level assessment is a PR assessment. Various approaches and methodologies have been proposed to assess the PR of NES facilities. An international approach being developed and supported by the Generation IV International Forum (GIF) PR and Physical Protection (PR\&PP) working group uses defined proliferation measures and incorporates structured expert elicitation. This methodology uses pathway analysis to evaluate different scenarios in NES facilities that could result in nuclear proliferation by considering five potential host-State proliferation strategies: concealed diversion, overt diversion, concealed facility misuse, overt facility misuse, and independent clandestine facility use.

In the GIF approach, specific scenarios, referred to as pathways, are defined. A pathway is a combination of a proliferation strategy and target and is divided into three major stages: materials acquisition, material processing, and weaponization. The GIF approach evaluates each pathway using six measures, the first four of which are intrinsic features of the system, and the last two of which are both intrinsic and extrinsic features. The measures are: 1) technical difficulty, 2) proliferation cost, 3) proliferation time, 4) fissile material type, 5) detection probability, and 6) detection resource efficiency. 
Despite the primarily technical nature of this approach as one that consists largely of identifying and evaluating the physical proliferation possibilities, the six PR measures have social aspects to them. Proliferation theories can be used to identify behavioral, social, and cultural factors that explain the motivation of a country or organization to develop nuclear weapons. Consideration of the behavioral, social, and cultural factors can be more explicitly integrated into consideration of the proliferation measures against proliferation pathways. In this way social factors could be used to inform NES design (i.e., intrinsic characteristics) and safeguards (i.e., extrinsic characteristics) improvement. Bayesian Networks (BNs) and other analytical methods could be used to integrate the social and technical models.

We constructed a BN based on proliferation factors identified by Singh and Way and data they gathered to perform quantitative tests. We built three models: one each for explore, pursuit, and acquire; and one that contains all three of these. Singh and Way are among the few analysts who have attempted to put proliferation theories to a quantitative test by using regression models to test the strength of the relationship between the decision to proliferate and predictive variables. We built the BNs to leverage its analytical capability and with future ambitions in mind, but used the Singh and Way data to inform the model.

An important question is which of the independent variables are the best predictors among those examined by Singh and Way. Although Singh and Way report which independent variables are significant in predicting proliferation, it is difficult to determine what their relative importance is. One way to address this question is through the diagnosticity of the variables in the BN. Diagnosticity is the ability to distinguish among hypotheses. Intuitively, the greater the diagnosticity of a variable, the more useful it is in reducing the uncertainty about the hypothesis under investigation - in this case whether a country has acquired nuclear weapons. The diagnosticity calculation is based on the amount of potential entropy reduction. The diagnostic value is the difference between the uncertainty of the prior distribution and the expectation of the uncertainty in the posterior distributions, where the expectation is uncertainty in the posterior distributions weighted by the preposterior distributions. The greater the diagnosticity of a predictor the larger the impact it will have in deciding whether a State is acquiring nuclear weapons. Variables with the highest diagnostic value are the most helpful in deciding among the competing hypotheses (acquiring or not) because they will have the greatest impact on reducing the uncertainty.

Variables determined to have the highest diagnostic value using this preliminary model are:

- Industry 2: Energy, electricity, and steel production and consumption. Supplements Industry 1 with per-capita and aggregate data on energy consumption, electricity production and generating capacity, and steel production.

- Disputes: 5-year moving average of the number of militarized interstate disputes per year in which the State is involved.

- GDPCAP: GDP per capita. The value of all final goods and services produced within a State in a given year divided by the average population for the same year. Provides an indicator of economic development, which is closely linked to sophisticated technical, engineering, and manufacturing knowledge.

- $\mathrm{G}^{2}$ : GDP squared. Indicates the size of the overall economy. The value was squared to account for the fact that the relationship between GDP and nuclear weapons production is not linear because weapons production occurs in an "economy of scale." 
- Industry 1: Measure of level of industrial capability based on electricity generation and domestic steel production.

- Polity: Democracy or autocracy level per country in a given year.

- Rivalry: Participation in an enduring rivalry, used to indicate a substantial and ongoing security threat (True or False for every year).

These factors should be considered in developing a reference set of threats to evaluate the NES against the threat associated with a specific location. Engagement with the GIF PR\&PP working group is being pursued to determine whether and to what degree the social factors identified by the social modeling have an impact in assessing a NES using the six GIF proliferation resistance metrics.

The BN model using the Singh and Way dataset is a preliminary model in the earliest stage of development. The structure comes from Singh and Way and is consistent with the literature on proliferation in that the variables used are suggested by the literature as important. However, we envision a larger, more BN comprehensive model that would make use of the Singh and Way dataset as well as other datasets such as the Jo and Gartzke dataset, and variables reported in an earlier project report. The virtues of $\mathrm{BN}$ models for analysis and exploration include:

- They are easy to run cases specific to a particular country,

- Readily available software displays the models and supports direct interaction with the models.

- Software calculates diagnostic information indicating importance of model components;

- They can combine variables from several models;

- They can make use of datasets supplemented with expert judgment where data is not available;

These models provide a mechanism to explore the Singh and Way data and related models. These activities will be pursued in further research, which involves developing a State-level model and how to expand to multiple locations or facilities within a country. 



\section{Acknowledgments}

This report represents work funded by the DOE/NNSA Office of Nonproliferation Research and Development (NA-22). 



\section{Acronyms and Abbreviations}

\begin{tabular}{|c|c|}
\hline AFCI & Advanced Fuel-Cycle Initiative \\
\hline $\mathrm{BN}$ & Bayesian Network \\
\hline COW & Correlates of War \\
\hline $\mathrm{DE}$ & Detection Resource Efficiency \\
\hline DOE & U.S. Department of Energy \\
\hline DoD & U.S. Department of Defense \\
\hline $\mathrm{DP}$ & Detection Probability \\
\hline ESFR & Example Sodium Fast Reactor \\
\hline GDP & gross domestic product \\
\hline $\mathrm{G}^{2}$ & gross domestic product squared \\
\hline GIF & Generation IV International Forum \\
\hline HEU & highly enriched uranium \\
\hline IAEA & International Atomic Energy Agency \\
\hline INMN & Institute of Nuclear Materials Management \\
\hline INPRO & International Project on Innovative Nuclear Reactors and Fuel Cycles \\
\hline IOS & individual, organizational, and societal (model) \\
\hline MAUA & multi-attribute utility analysis \\
\hline MID & Militarized Interstate Disputes \\
\hline MT & Fissile Material Type \\
\hline NES & nuclear energy systems \\
\hline NMA & nuclear material accounting \\
\hline NNSA & National Nuclear Security Administration \\
\hline NNWS & Non-Nuclear Weapons State \\
\hline NPAM & Nonproliferation Assessment Methodology \\
\hline NPT & Nuclear Nonproliferation Treaty \\
\hline NRC & U.S. Nuclear Regulatory Commission \\
\hline NWFZ & Nuclear Weapons-Free Zone \\
\hline $\mathrm{PC}$ & Proliferation Cost \\
\hline PR & Proliferation Resistance \\
\hline PT & Proliferation Time \\
\hline PR\&PP & Proliferation Resistance and Physical Protection \\
\hline PWR & Pressurized Water Reactor \\
\hline RTS & Reference Threat Set \\
\hline SAM & Simulation, Algorithms \& Modeling \\
\hline SLA & State-Level Approach \\
\hline SNM & special nuclear material \\
\hline
\end{tabular}


SQ

TD

$\mathrm{V} \& \mathrm{~V}$

$\mathrm{VV} \& \mathrm{~A}$

WMD significant quantity

(Proliferation) Technical Difficulty

verification and validation

verification, validation, and accreditation

weapons of mass destruction 


\section{Contents}

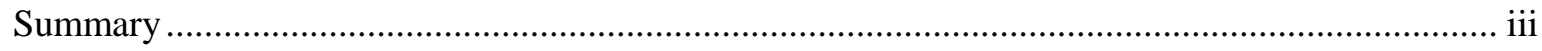

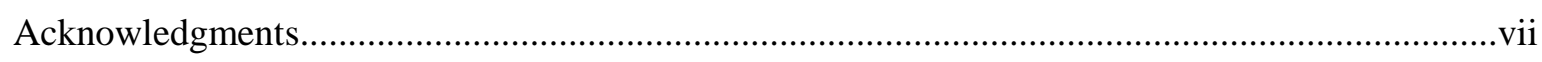

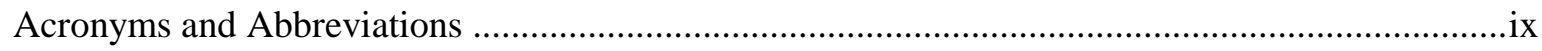

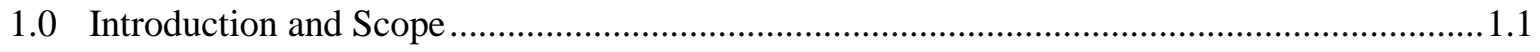

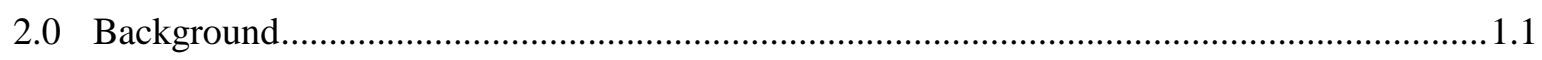

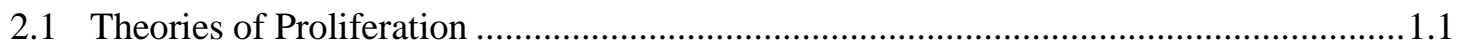

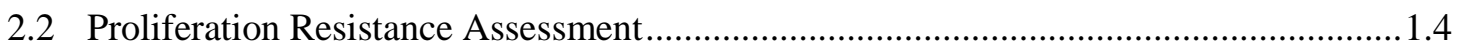

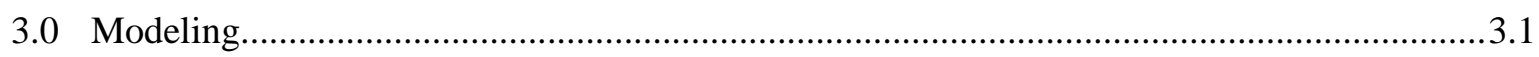

3.1 Using Social Modeling to Determine Relevant Social Factors ....................................... 3.1

3.1.1 Descriptions of the Singh and Way Data Variables ............................................3.3

3.1.2 Quantitative Analysis Performed by Singh and Way ............................................ 3.6

3.1.3 Quantitative Analysis Using BN Model........................................................... 3.8

3.1.4 Using Quantitative Analysis of Singh and Way Dataset to Enhance GIF Model 3.9

3.1.5 Future BNModel Development and Quantitative Analysis................................3.11

3.2 Proposal for Enhancing the GIF Assessment Method....................................................13

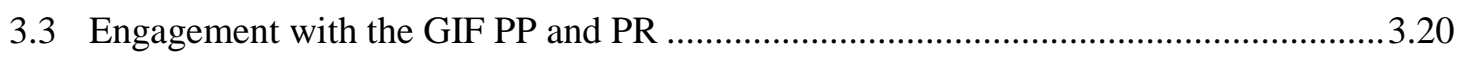

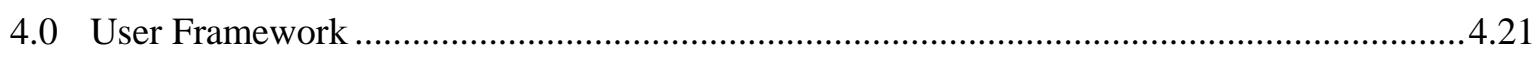

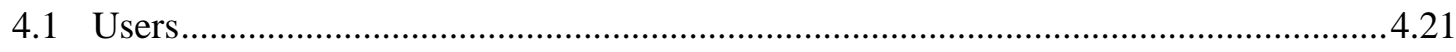

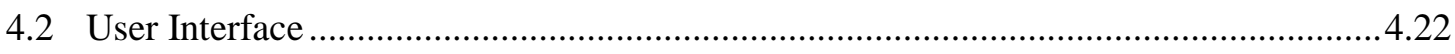

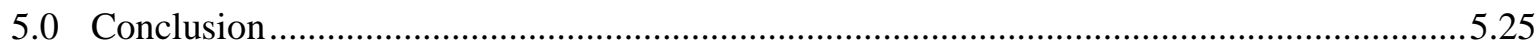

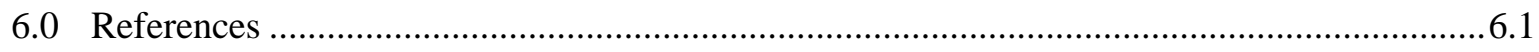

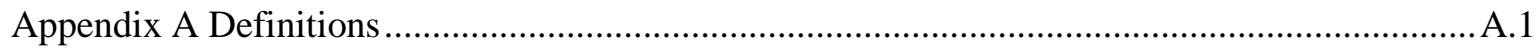

Appendix B Expert Questionnaire .................................................................................... B. 


\section{Figures}

Figure 3.1. Conceptual Model to Predict Proliferation Based on Singh and Way Variables ..........3.2

Figure 3.2. BN Constructed using Singh and Way Dataset ..........................................................

Figure 3.3. Tentative Relationship between Singh and Way Predictor Variables and Diagnosticity3.10

Figure 3.4. Social Versus Technical Resistance to Proliferation. 3.15

\section{Tables}

Table 2.1. Comparison of Nuclear Nonproliferation Theories .................................................... 1.2

Table 3.1. Definition of Singh and Way Variable Names ........................................................... 3.2

Table 3.2. Diagnosticity of Predictive Variables for Acquire, Given no Information ....................3.7

Table 3.3. Social Factors Defined by the BN Analysis with Descriptions and Example Countries

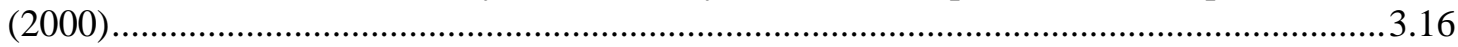

Table 3.4. Expert Questionnaire Form - Diversion Pathway ..................................................... 3.20

Table 3.5. Results from Expert Questionnaire - Misuse Pathway ...............................................3.20

Table 4.1. Users and Uses (from Pomeroy [1]) ....................................................................2. 


\subsection{Introduction and Scope}

The Utility of Social Modeling for Proliferation Assessment project (PL09-UtilSocial) investigates the use of social and cultural information to improve nuclear proliferation assessments, including nonproliferation assessments, Proliferation Resistance (PR) assessments, safeguards assessments, and other related studies. These assessments often use and create technical information about a host State and its posture towards proliferation, the vulnerability of a nuclear energy system (NES) to an undesired event, and the effectiveness of safeguards. The objective of this project is to find and integrate social and technical information by explicitly considering the role of cultural, social, and behavioral factors relevant to proliferation; and to describe and demonstrate if and how social science modeling has utility in proliferation assessment.

This report describes a modeling approach and how it might be used to support a location-specific assessment of the PR assessment of a particular NES. The report demonstrates the use of social modeling to enhance an existing assessment process that relies on primarily technical factors. This effort builds on a literature review and preliminary assessment performed as the first stage of the project and compiled in PNNL-18438. [1] This second report represents the culmination of the first year of research.

This report describes an effort to answer questions about incorporating social modeling into a PR assessment in such a way that the effects of social factors on a primarily technical assessment can be determined. This report provides:

1. background information about relevant social factors literature;

2. background information about a particular PR assessment approach relevant to this particular demonstration;

3. a discussion of social modeling undertaken to find and characterize social factors that are relevant to the PR assessment of a nuclear facility in a specific location;

4. description of an enhancement concept that integrates social factors into an existing, technically based nuclear facility assessment;

5. a discussion of a way to engage with the owners of the PR assessment methodology to assess and improve the enhancement concept;

6. a discussion of implementation of the proposed approach, including a discussion of functionality and potential users; and

7. conclusions from the research.

This report represents technical deliverables for the NA-22 Simulations, Algorithms, and Modeling program. Specifically this report is the Task 2 and 3 deliverables for project PL09-UtilSocial. 



\subsection{Background}

Based on the literature review and preliminary assessment conducted in the first stage of this project [1], we have concluded that there are opportunities to use social models to improve the understanding and assessment of proliferation-related problems. Analysts, primarily political scientists, have theorized about various factors that may indicate whether a State pursues the development of nuclear weapons. For the purposes of this research, we refer to these indicators as "social factors." The social factors included in this analysis include indicators such as national identity, leadership, politics, domestic security, and economic capability. Social modeling offers a way to leverage this body of analysis and theory to support proliferation assessments.

PNNL-18438 identifies opportunities for social modeling to support two principal types of assessments. First, social modeling can support overarching kinds of assessment, such as State-level analyses like the International Atomic Energy Agency's (IAEA's) State-Level Approach (SLA) for international safeguards through an integrated analysis of nuclear activities taking place within a State. Second, social modeling can improve specific assessments, such as facility-level assessments like the Generation IV International Forum (GIF) Evaluation Methodology for PR and Physical Protection (PR\&PP) through an improved mechanism to define the threat against which the evaluated NES must stand.

This section provides background discussion (see $P N N L-18438$ for details) germane to the modeling concept presented in this report. First, this section explains the theories of proliferation and how they relate to social factors. Next, this section introduces the role of PR assessments and identifies two methodologies for conducting them that have gained acceptance and are currently being used.

\subsection{Theories of Proliferation}

Since the advent of nuclear weapons, scholars and policy-makers have grappled with the challenge of stopping the proliferation of nuclear weapons. Scholars have debated the causes of State-sponsored nuclear proliferation and attempted to determine its predictability. Analysts have advanced a substantial number of theories to explain nuclear proliferation and have often tried to support those theories using case studies. As nonproliferation research evolved, a few quantitative studies have emerged. During this development of nonproliferation thinking, theorists built a shared vocabulary and common conceptualizations to help explain and differentiate theories.

These theories generally attempt to evaluate the capabilities and willingness of State proliferators to undertake an effort to develop or acquire a nuclear weapons capability. These theories define key causes, factors, or determinants that influence the decision of a country to develop nuclear weapons. These factors are organized and described differently under each theory, but this research team classified them into the following groups:

1. Technical capability

2. National and international security

3. Domestic politics

4. National identity and psychology.

Tables 2.1 illustrates the social factors used by several analysts to describe their proliferation theory. 
Table 2.1. Comparison of Nuclear Nonproliferation Factors

\begin{tabular}{|c|c|c|c|c|}
\hline Source & $\begin{array}{c}\text { Technical Capability } \\
\text { Factors } \\
\end{array}$ & $\begin{array}{c}\text { International Security } \\
\text { Factors } \\
\end{array}$ & Domestic Politics Factors & $\begin{array}{l}\text { National Identity \& } \\
\text { Psychology Factors }\end{array}$ \\
\hline Singh and Way [2] & $\begin{array}{l}\text { - Latent capability }{ }^{(a)} \\
\text { - Economic capacity }\end{array}$ & $\begin{array}{l}\text { - Security threat } \\
\text { - Security alliance }\end{array}$ & $\begin{array}{l}\text { - Regime type } \\
\text { - Political change } \\
\text { - Economic openness } \\
\text { - Economic change }\end{array}$ & - Symbolism $^{(b)}$ \\
\hline Sagan [3] & - Latent capability & - Nuclear threat & 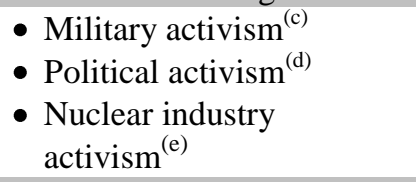 & $\begin{array}{l}\text { - Symbolism } \\
\text { - Institutional isomorphism } \\
\text { (f) }\end{array}$ \\
\hline Jo and Gartzke [4] & $\begin{array}{l}\text { - Latent capability } \\
\text { - Technology diffusion } \\
\text { - Economic capacity }\end{array}$ & $\begin{array}{l}\text { - Security threat } \\
\text { - Security alliance } \\
\text { - Diplomatic isolation }\end{array}$ & $\begin{array}{l}\text { - Regime type } \\
\text { - Domestic unrest }\end{array}$ & $\begin{array}{l}\text { - Symbolism } \\
\text { - International norms }\end{array}$ \\
\hline Rublee [5] & & & $\begin{array}{l}\text { - Activism (for and } \\
\text { against) }^{(\mathrm{g})}\end{array}$ & $\begin{array}{l}\text { - Consistency }{ }^{(\mathrm{h})} \\
\text { - Linking with established } \\
\text { values }^{(\mathrm{i})}\end{array}$ \\
\hline Hymans [6] & & & & - National identity consensus \\
\hline Epstein [7] & & $\begin{array}{l}\text { - Security threat } \\
\text { - Security alliance } \\
\text { - Weapons superiority }\end{array}$ & $\begin{array}{l}\text { - Nuclear hedging }{ }^{(\mathrm{j})} \\
\text { - Legal barriers }\end{array}$ & $\begin{array}{l}\text { - Symbolism } \\
\text { - International norms } \\
\text { - Regional status } \\
\text { - International status } \\
\text { - Economic status }\end{array}$ \\
\hline Mozley [8] & & $\begin{array}{l}\text { - Security threat } \\
\text { - Diplomatic isolation }\end{array}$ & - Regime type & - Regional status \\
\hline Reis and Litwak [9] & $\begin{array}{l}\text { - Latent Capability } \\
\text { - Technology diffusion } \\
\text { - Economic capacity } \\
\text { - Technological difficulty } \\
\text { - Materials diffusion } \\
\text { - Support from advanced } \\
\text { States }\end{array}$ & $\begin{array}{l}\text { - Security threat } \\
\text { - Security alliance } \\
\text { - Nuclear threat } \\
\text { - Diplomatic isolation } \\
\text { - Relationship w/ U.S. } \\
\text { - Bargaining tool }{ }^{(\mathrm{k})} \\
\text { - U.S. policy }\end{array}$ & $\begin{array}{l}\text { - Regime type } \\
\text { - Domestic unrest } \\
\text { - Activism (for and against) } \\
\text { - Gov’t Legitimacy }{ }^{(1)} \\
\text { - Hedging } \\
\text { - Leadership } \\
\text { - Political change } \\
\text { - Economic change } \\
\end{array}$ & $\begin{array}{l}\text { - Symbolism } \\
\text { - International norms } \\
\text { - Regional status } \\
\text { - Prestige }{ }^{(\mathrm{m})} \\
\text { - } \text { NWFZ }^{(\mathrm{n})} \\
\text { - Nationalism } \\
\text { - Nuclear Phobia } \\
\text { - }{ }^{(\mathrm{o})}\end{array}$ \\
\hline
\end{tabular}


Table 2.1. (contd)

\begin{tabular}{|c|c|c|c|}
\hline & Technical Capability Factors & International Security Factors & Domestic Politics Factors \\
\hline (a) & \multicolumn{3}{|c|}{$\begin{array}{l}\text { Latent Capability - A factor related to a State's technical and industrial capacity that allows it to b } \\
\text { program. }\end{array}$} \\
\hline (b) & \multicolumn{3}{|c|}{$\begin{array}{l}\text { Symbolism - A factor related to the idea that nuclear weapons can also play an important symbolic role in a State's self-image. Nuclear weapons can be } \\
\text { imagined as fulfilling functions similar to those of flags, airlines, and Olympic teams. }\end{array}$} \\
\hline (c) & \multicolumn{3}{|c|}{ Military Activism - Efforts of the military to convince decision-makers that a nuclear weapon is, or is not, in the State's best interest. } \\
\hline (a) & \multicolumn{3}{|c|}{ Political Activism - Efforts of politicians to convince decision-makers that a nuclear weapon is, or is not, in the State's best interest. } \\
\hline (c) & \multicolumn{3}{|c|}{ Nuclear Industry Activism - Efforts of the nuclear industry to convince decision-makers that a nuclear weapon is, or is not, in the State's best interest. } \\
\hline (1) & \multicolumn{3}{|c|}{$\begin{array}{l}\text { Institutional Isomorphism - A factor is related to the concept that individuals and institutions naturally begin to mimic one another because of the normative } \\
\text { requirements of each individual or institution. The concept argues that a State will build a nuclear weapon because "that is what a powerful State does." In } \\
\text { essence, institutional isomorphism is a concept of normative behavior [3]. }\end{array}$} \\
\hline (g) & \multicolumn{3}{|c|}{ Activism - General efforts by anyone to convince decision-makers that a nuclear weapon is, or is not, in the State's best interest. } \\
\hline (h) & \multicolumn{3}{|c|}{$\begin{array}{l}\text { Consistency - A factor is related to social psychology and the belief that historical behavior is a good indicator of future behavior because the need to be, } \\
\text { and appear, consistent is a powerful motivator for action. [5; p. 427] }\end{array}$} \\
\hline (i) & \multicolumn{3}{|c|}{ Linking with Established Values - The act of connecting a new social norm to well-established values. [5; p. 435] } \\
\hline ( & \multicolumn{3}{|c|}{$\begin{array}{l}\text { Nuclear Hedging - Refers to any action to either enhance or destroy a nuclear weapons program or a nuclear weapon because of actions that could happen } \\
\text { in the future. For example, a State may attempt to develop a nuclear weapons CAPABILITY rather than a nuclear weapon to avoid backlash from the } \\
\text { international community in the short term. Also, a State may give up a nuclear weapon to prevent a future government from gaining access to the weapons } \\
\text { (the apartheid government of South Africa). }\end{array}$} \\
\hline$(\mathrm{k})$ & \multicolumn{3}{|c|}{$\begin{array}{l}\text { Bargaining Tool - Some States may attempt to acquire either a nuclear weapons program, or a nuclear weapon, as a bargaining chip in negotiations with a } \\
\text { State that has more real leverage. For example, North Korea agreed to give up its plutonium production to receive concessions from the six-party talks. }\end{array}$} \\
\hline (1) & \multicolumn{3}{|c|}{$\begin{array}{l}\text { Legitimacy of Government - A government may pursue a nuclear weapons program or a nuclear weapon to prove that it is capable of defending the State in } \\
\text { an effort to build legitimacy. }\end{array}$} \\
\hline & \multicolumn{3}{|c|}{$\begin{array}{l}\text { Prestige - A State may pursue nuclear weapons to show off its science and engineering capabilities. This factor is closely related to both "symbolic" and } \\
\text { "status." }\end{array}$} \\
\hline (n) & \multicolumn{3}{|c|}{$\begin{array}{l}\text { NWFZ - Nuclear Weapons-Free Zone. Membership in a nuclear weapons-free zone may prevent a State from pursuing nuclear weapons becal } \\
\text { normative factors related to group consensus, as well as improved transparency. }\end{array}$} \\
\hline & \multicolumn{3}{|c|}{ aclear-phobia - Some States may have a social aversion to nuclear weapons that makes tha } \\
\hline
\end{tabular}


The factors based on State behavior are not an exclusive list; other factors could include individual and group behavioral research. The abundance of data, discussion, and analysis of State-level social factors makes this information attractive to leverage at this stage of the project to demonstrate their utility in facility-level assessment.

\subsection{Proliferation Resistance Assessment}

In a recent Newsweek article [10], Henry Kissinger highlighted the importance of developing proliferation-resistant nuclear technologies: "A critical issue in nonproliferation strategy will be whether the international community can place the fuel cycle for peaceful uses of nuclear energy under international control. Is the IAEA capable of designing a system that places the enrichment and processing of uranium and plutonium under international control and in the locations (emphasis added) that do not threaten nuclear proliferation?"

PR assessments evaluate an NES, or sub-system, to determine a measure of its ability to withstand diversion or misuse that would contribute to nuclear proliferation. PR assessments are performed either in the context of a particular threat, or in a contextual vacuum considering only technical characteristics from the NES itself. PR assessments can include intrinsic factors (those characteristics built-in to a system that contribute to its PR, such as design barriers) [11] [12] [13], extrinsic barriers (external forces placed on a system that inhibit proliferation, such as safeguards mechanisms) [11], or both.

Technical assessments can grade technologies, but tend to leave out important components of PR like location, which is something that Dr. Kissinger noted as a concern in his piece quoted above. Social modeling can also help assess extrinsic features like norms of behavior (international control) that a technical assessment cannot.

There are two PR assessment methodologies that are currently under active development by the international community. They are:

1. the Generation IV International Forum (GIF) Evaluation Methodology for PR\&PP [14] ${ }^{1}$; and

2. the IAEA-sponsored Methodology for the Assessment of Innovating Nuclear Reactors and Fuel Cycles (INPRO) [15].

This report focuses on the GIF methodology. The GIF working group ${ }^{2}$ recommends that the PR assessment be performed across a Reference Threat Set (RTS), which is defined as "... a collection of well-defined threats that is to be consistently considered and is the foundation for any level of $P R$ (proliferation resistance) or PP (physical protection) assessment..." [12]. The group also recommends that the RTS should be developed at the design stage of a system and re-evaluated once the facility is constructed.

\footnotetext{
${ }^{1}$ The GIF is developing next-generation energy system and nuclear reactor technologies to be deployed by 2030 . Technology goals of the GIF highlight PR\&PP along with sustainability, safety, reliability, and economy.

${ }^{2}$ The GIF was chartered in July 2001 to lead the collaborative efforts of the world's leading nuclear technology nations to develop next-generation nuclear energy systems to meet the world's future energy needs. The nine GIF founding members were joined by Switzerland in 2002, Euratom in 2003, and most recently, China and Russia at the end of 2006.
} 
Threat characterization provides an opportunity to infuse social factors information into the assessment. The approach for integrating social modeling into the GIF methodology is in Section 3.0 of this report. 



\subsection{Modeling}

One key to integrating social factors into a facility assessment was building a preliminary model to analyze the factors identified by scholars that influence proliferation attempts. These factors were then used to build threat characterizations for the GIF PR\&PP assessment methodology to demonstrate the model's utility to enhance a primarily technical process.

This section of the report focuses first on the modeler's approach to building the facility-level model, second, on one method of applying the facility model to PR assessments, and third, on engagement with the GIF PR\&PP group.

\subsection{Using Social Modeling to Determine Relevant Social Factors}

Existing literature on theories of State-sponsored proliferation is abundant and goes back to the decades following World War II and the signing of the Nuclear Nonproliferation Treaty (NPT). Many of the theories and articulation of incentives and disincentives for countries to go nuclear were formed in the cold war era and still play a significant role in the ongoing debate. In the cold war era there was a clear emphasis on international security as the dominant factor. Epstein [1] argues, "The dominant positive and negative incentives to go or not to go, nuclear are those involving a country's military security. Problems of military security are paramount questions for all governments, and in the absence of any other satisfactory way of ensuring it, defense based on military force is the customary preferred path." In other literature, this concept has been referred to as the "realist view" or the "security model." In the cold war era, Meyers [2] argued that a State's ability to be in a secure alliance to one of the two nuclear super powers was the decisive factor as to whether a country would pursue nuclear weapons. However, even in this era it was acknowledged that political and economic motivations were also important factors, such as strengthening independence and increasing status and prestige in the world. Another theory of proliferation, known as the technological imperative, holds that during the natural evolution of a State from a non-industrial to an industrialized society, it would acquire the knowledge, technology, and the economic means to develop nuclear weapons. Based on this theory once a State had acquired this "latent capacity" it was just a matter of time until the natural momentum of this capacity would result in the acquisition of nuclear weapons [2].

While historically analysts tested their theories empirically very few studies have developed quantitative models that explored the relative importance of the individual variables as indicators of proliferation. Singh and Way [3] quantitatively tested these competing theories by using regression models to examine the strength of the relationship between the decisions to proliferate and predictive variables. The authors organize the variables into three categories: Technological Determinants, External Determinants, and Domestic Determinants. Technological Determinants are variables concerning the technological and industrial capacity to build nuclear weapons. External Determinants are related to the political stability within the region and whether a State has a nuclear protector. Domestic Determinants refer to the internal conditions of the State, such as the degree of democratization and economic interdependence. A conceptual model extracted from their study is shown in Figure 3.1. Variables shown in green are the ones used by Singh and Way in their regression model. We discuss the meaning of each of these variables and provide brief descriptions along with their ranges in Table 3.1. 


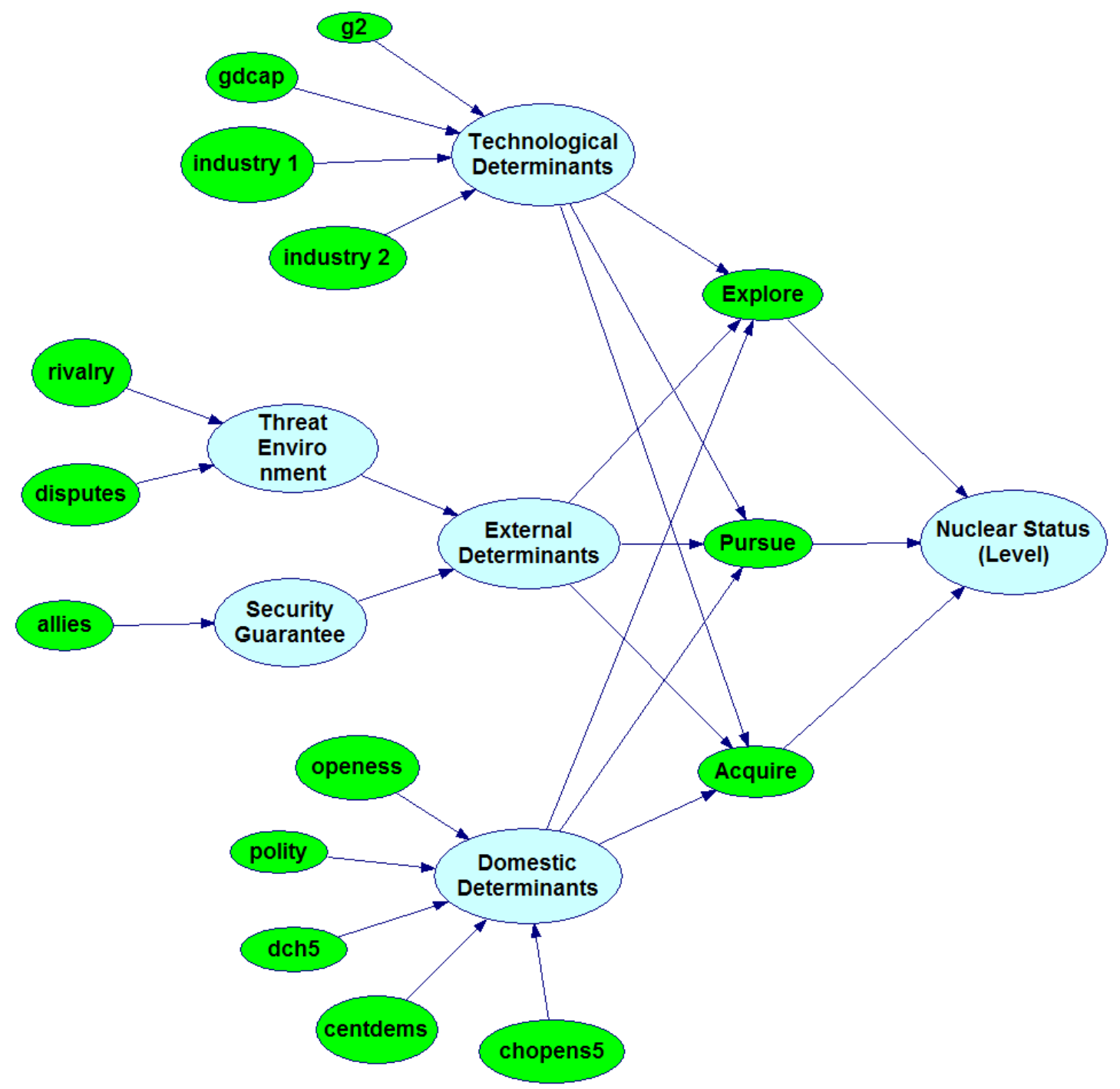

Figure 3.1. Conceptual Model to Predict Proliferation Based on Singh and Way Variables

Table 3.1. Definition of Singh and Way Variable Names

\begin{tabular}{lll}
\hline Variable & Description & Scale \\
\hline GDPCAP & GDP per Capita & 281 to 44,000 \\
$\mathrm{G}^{2}$ & GDP squared & 79,000 to 1.94E+09 \\
Industry1 & Index based on steel production \& electrical generating capacity & Coded as 0 or 1 for True or False \\
Industry2 & Index based on Industry 1 and energy onsumption & Coded as 0 or 1 for True or False \\
rivalry & Presence of an enduring rivalry & Coded as 0 or 1 for True or False \\
disputes & Frequency of disputes & Number of disputes (0-18) \\
allies & Presence of a great power alliance & Coded as 0 or 1 for True or False \\
polity & Openness/status of democracy & Scaled -10 to 10 \\
centdems & Percentage of democracies at regional level & Minimum: 21.95; Maximum: 37.11 \\
openness & Level of economic interdependence & Minimum: 0.03; Maximum: 770 \\
chopen5 & Level of economic liberalization & Minimum: -287; Maximum: 352 \\
\hline
\end{tabular}




\subsubsection{Descriptions of the Singh and Way Dataset Variables}

$\underline{\text { GDP }}$

Singh and Way use two different measures for GDP to judge the level of economic development present in a State during a specific timeframe. The measures are GDP per capita (GDPCAP) and GDP squared $\left(\mathrm{G}^{2}\right)$. GDP is an important measure, because the relative cost of a nuclear weapons program is extremely high.

GDP per capita is determined from the Penn World Tables. ${ }^{1}$ The value ranges from 281 to 44,000 and is a measure of a State's production value per person. The authors wished to convey the importance of GDPCAP over GDP because they were trying to assess is economic development, which generally goes hand in hand with higher worker productivity.

GDP squared is denoted in the Singh and Way Dataset as "G2" and is the square of a State's GDP. The data is taken from the Penn World Tables and is it is squared to account for the possibility that the relationship between a State's economic development and its nuclear weapons development is curvilinear ${ }^{2}$.

\section{Industrial Capacity Index}

Industrial Capacity Index is denoted in the Singh and Way dataset as either "industry 1" or "industry 2." The Industrial Capacity index is a True or False $(0,1)$ statement in the dataset indicating that a State is a producer of domestic steel and has installed electricity-generating capacity over $5000 \mathrm{MWe}$. We consider Industrial Capacity a prerequisite to pursuing a nuclear weapons program.

\section{Security Guarantee (Allies)}

Security Guarantees are denoted in the Singh and Way dataset as "allies" and it is coded as either True or False $(1,0)$. Singh and Way define a security guarantee as one State having a defense pact with a great power State. Great power State are defined based on Singer and Small's standard list of great powers, and consists of the United States, Russia, the United Kingdom (from 1952 forward), France (from 1960 forward), and China (from 1964 forward) [4]. The data for coding which States had defense pacts comes from the Correlates of War (COW) data [5].

It is often assumed that a nuclear umbrella negates the need for a nuclear weapons capability. This argument is often used to support need for the North Atlantic Treaty Organization nuclear umbrella and was recently cited by the Secretary of State as a justification to prevent a nuclear arms race in the Middle East and North Africa against Iran [6]. One of the longstanding arguments against U.S. disarmament efforts is that the U.S. nuclear umbrella helps nonproliferation measures by giving an implied nuclear weapons capability to non-nuclear States and takes away those States' need to develop a nuclear deterrent [7]. Singh and Way do not specifically count "nuclear umbrella" agreements, but cite "defense pacts," which have mostly the same effect, because they require an all-out defense of a pact-State in the event of war. Theoretically, this could include nuclear retaliation.

\footnotetext{
${ }^{1}$ Penn World Tables, v6.1

${ }^{2}$ Penn World Tables, v6.1
} 


\section{Enduring Rivalry (Rivalry)}

Enduring Rivalries are denoted in the Singh and Way dataset as "rivalry" and the value is either True or False $(1,0)$, depending on whether a State was involved in one or more enduring rivalries in a given year's time (from Bennett's data on Enduring Rivalries) [8].

Enduring Rivalries are considered important because they could drive a State to engage in military competition to maintain a material advantage or avoid a material disadvantage vis-à-vis an opponent. The authors state that "The vast majority of wars and militarized interstate disputes (MIDs) occur in the context of Enduring Rivalries [9].” A good example would be the Cold War.

\section{Frequency of Dispute Involvement (Disputes)}

Frequency of Dispute Involvement is denoted in the Singh and Way dataset as "disputes" and is a value ranging from 0 to 17.75 based on a 5-year moving average of the number of militarized interstate disputes per year in which a State is involved. It is based on the MID and its maximum value is limited only by the number of disputes a State can enter in any given year [9]. MIDs are defined as instances where one State directs military force, even short of all-out war, against another State's government, employees, military forces, or territory. A high value listed under "disputes" in the dataset indicates a high level of regional insecurity.

The frequency of MIDs is included because many authors believe that an insecure or unstable security environment drives a State to strengthen its military [10]. Realists generally consider nuclear weapons to have a substantial deterrent effect, which would benefit a State that experiences high levels of insecurity. This assumption about deterrence is one of the reasons the authors felt it important to include security guarantees in the study. The security guarantee is intended to strengthen a State's military capability, whether nuclear or conventional, and increase its deterrence effect, which should increase the level of stability and feeling of security in a State. This assumes that a State is the victim of aggression.

Alternatively, the frequency of MIDs a State is involved in as the aggressor could indicate a State's willingness to engage in overwhelming force or coercion to accomplish its foreign policy objectives. Nuclear weapons give aggressive States an additional offensive or defensive tool and may bolster their military capabilities.

\section{Democracy}

Singh and Way measured the type of government and the status of democracy by examining three variables: Democracy, Democratization, and the Prevalence of Democracies which are discussed in greater depth in the following.

\section{Democracy (Polity)}

Democracy is denoted in the Singh and Way dataset as "polity" and is a value ranging from -10 to +10 derived from the Polity IV scales of democracy and autocracy, which measure democracy ("democ") on a scale of 0-10 and autocracy ("autoc") on a scale of $0-10 .{ }^{3}$ Polity is defined as:

\footnotetext{
${ }^{3}$ Polity IV Project. 2000. "Regime Authority Characteristics and Transitions Datasets." This dataset is from 2000.
} Accessed September 29, 2009, at http://www.systemicpeace.org/inscr/inscr.htm. 


$$
\text { polity }=\text { democ }- \text { autoc }
$$

A State with a high positive value on the democracy scale exhibits the traits of a highly democratic State while a State scoring low on the scale exhibits the traits of a highly autocratic State.

The role of a structure of government in qualitative nonproliferation literature is hotly debated. Some realist authors believe that democracies are more likely to proliferate if faced with a security threat than autocracies. This assumes that a democratic populace will respond to a threat by balancing it with a deterrent. Alternatively, some scholars tend to assume that autocracies (which are considered irrational and bad for the system) will tend to proliferate more often because they are less likely to adhere to international norms and demand openness from their leaders.

\section{Democratization (dch5)}

Democratization is denoted in the Singh and Way dataset as "dch5" and is a time-sensitive value based on the "polity" factor (listed above as "Democracy"). It measures movement towards "fulldemocracy" (+10) over a 5-year period. Dch5 is defined as:

$$
\mathrm{dch}_{5}=\text { Polity }_{\mathrm{t}}-\text { Polity }_{\mathrm{t}-5}
$$

Its value ranges from -18 to +18 in the dataset. A high value indicates a strong change in favor of democracy and a low value indicates a strong change in favor of autocracy. A value of zero indicates no change.

Democratization is included in this study and in qualitative literature because some authors believe changes in the domestic status quo affect a State's need to validate its rule. By moving away from autocracy, some leaders may desire a new source of authority and legitimacy, which some people believe a nuclear weapon confers. Singh and Way attempted to find the correlation between a State changing the structure of its government and its desire to acquire a nuclear weapon to prove a State has the authority and power to protect its sovereignty.

\section{The Prevalence of Democracies (centdems)}

Prevalence of Democracies is denoted in the Singh and Way dataset as "centdems" and it is the percentage of States with a score of 7 or higher on the "democracy scale" from the factor "polity" (listed as Democracy above), within a State's immediate region. The region is coded according to the COW State system membership data. ${ }^{4}$ In the data, $21.95 \%$ is the lowest Prevalence of Democracies and $37.11 \%$ is the highest Prevalence of Democracies.

The Prevalence of Democracies is important in qualitative literature because there is a hotly contested debate between realists and democratic peace theorists. The democratic peace theory posits that democracies do not go to war with other democracies or engage in other behaviors that undermine the democratic system's stability or security. Therefore, a region of the world consisting primarily of democracies would be inclined to have less proliferation and stability for democratic States. However,

\footnotetext{
${ }^{4}$ Correlates of War Project. 2003. State System Membership List, v2002.1. Accessed September 29, 2009, at www.correlatesofwar.org.
} 
this is not the case for authoritarian States in a region of democracies because democracies do go to war with non-democratic States.

\subsubsection{Quantitative Analysis Performed by Singh and Way}

Singh and Way analyze their data using two different regression models: a hazard model and a logistics regression model. Ordinarily, a hazard model assumes a certain inevitability for example machines eventually fail. However, the particular functional form for the hazard model chosen by Singh and Way has a parameter that is empirically determined, that allows the hazard to either increase, decrease, or remain constant over time. The advantage of the logistic regression model is that the dependent variable is a probability. Unlike least-squares regression models, the regression coefficients in these models are difficult to interpret; in particular, the magnitude of the regression coefficients cannot be related to a specific change in the independent variable. The results from the hazard model are presented by Singh and Way in both the standard form and the log relative hazard forms. Log relative forms can be interpreted as an increase in likelihood. Unfortunately, these Singh and Way results are reported in different tables using inconsistent variable names. While it is apparent which variables have coefficients that are clearly significant (not equal to zero in a two-tailed test of significance), it is not clear for those variables that are less significant (many of which are significant at the .001 level) what their relative importance is. Table 3.2 summarizes some of their results as well as some results from a BN constructed using their dataset. The $\mathrm{BN}$ is discussed in more detail later in section 3.1.3. Table 3.2 lists the variables in the Singh and Way dataset. Variable names are listed in the first column and more intuitive names in the second column.

For the logistic model the impact of the coefficients is best judged by the significance level. Most of these have a significance of .001 and it is impossible to discriminate among their relative importance.

The column titled "Substantive Effects" indicates the relative impact the variables have on Acquire as the independent variable using the hazard function model, but information is not available for all the independent variables in the Singh and Way dataset. In summary, while one can determine which independent variable coefficients achieved significance, their relative importance is difficult to determine. 
Table 3.2. Comparison of Diagnosticity of Predictive Variables for Acquire with Results from Singh and Way Regression Models

\begin{tabular}{|c|c|c|c|c|c|c|c|}
\hline Indicator & Plain Text Name & $\begin{array}{l}\text { Diagnostic } \\
\text { Value }\end{array}$ & $\begin{array}{l}\text { Logit Model } \\
\text { Standard } \\
\text { Coefficients }\end{array}$ & $\begin{array}{l}\text { Logit Model } \\
\text { Significance }\end{array}$ & $\begin{array}{c}\text { Hazard } \\
\text { Model } \\
\text { Coefficients }\end{array}$ & $\begin{array}{l}\text { Hazard Model } \\
\text { Significance }\end{array}$ & $\begin{array}{l}\text { Substantive } \\
\text { Effects }(\%)\end{array}$ \\
\hline Industry 2 & Industrial Capacity Index ${ }^{1} *$ & 0.298 & 22.59 & .001 & 3.19 & $<.001$ & 2340 \\
\hline $\begin{array}{l}\text { Disputes } \\
\text { (highest) }\end{array}$ & Frequency of MIDs & 0.266 & 0.86 & .001 & .23 & .07 & +52 \\
\hline GDPCAP & GDP per Capita & 0.247 & 0.0004 & .001 & .0002 & .378 & NA \\
\hline $\mathrm{G}^{2}$ & GDP Squared & 0.242 & $-1.00 \mathrm{E} 08$ & .001 & $-2.4 \mathrm{E} 08$ & .100 & NA \\
\hline Industry 1 & Industrial Capacity Index & 0.198 & 22.59 & .001 & NA & NA & NA \\
\hline polity & Democracy-Autocracy Scale & 0.127 & 0.029 & 0.029 & .092 & .123 & NA \\
\hline rivalry & Enduring Rivalry & 0.104 & 1.61 & .001 & 2.13 & .076 & +743 \\
\hline chopens 5 & $\begin{array}{c}\text { Change in Economic Openness } \\
\text { (Interdependencies) over } 5 \\
\text { Years (moving average) }\end{array}$ & 0.058 & .003 & .675 & -.001 & .963 & NA \\
\hline openness & $\begin{array}{l}\text { Economic Openness } \\
\text { (Interdependencies) }\end{array}$ & 0.039 & -0.027 & .001 & .0002 & .989 & -2 \\
\hline dch5 & $\begin{array}{c}\text { Democratic Change over } 5 \\
\text { Years (moving average) }\end{array}$ & 0.037 & -0.023 & .334 & -.016 & .895 & +94 \\
\hline centdems 0.002 & $\begin{array}{l}\text { Percentage of Democracies in } \\
\text { the State's Region }\end{array}$ & 0.002 & 0.036 & .066 & -.094 & .351 & NA \\
\hline allies & $\begin{array}{c}\text { Presence of a Great Power } \\
\text { Alliance (Security Guarantee) }\end{array}$ & 0.001 & -1.25 & .001 & -1.01 & .225 & -64 \\
\hline
\end{tabular}

\footnotetext{
${ }^{1}$ The project team interpreted from the Singh and Way information "Industry 2" to be energy, electricity and steel production and consumption based on aggregate and per capita energy consumption, electricity production and generating capacity, and steel production per page 869 of their article [3].
} 


\subsubsection{Quantitative Analysis Using Bayesian Network Model}

We constructed a Bayesian network (BN) based on the conceptual model, shown in Figure 3.1, using the Singh and Way dataset. We built four models: one each for explore, pursuit, and acquire hypotheses; and one that contains all three hypotheses. The latter model is shown in Figure 3.2 and is capable of examining the relative probability of all three hypotheses concerning whether a State is exploring, pursuing, or acquiring nuclear weapons. The models are all naïve Bayesian classifiers, meaning the predictor variables are assumed to be independent. This is clearly not true in this case, but it is often claimed that naïve Bayesian models can be good predictors despite violations of independent assumptions [11][12].

We used the probability relationships from the Singh and Way dataset. These BN models [11] should provide similar results to logistic regression model of Singh and Way, which was one of two regressions carried out by Singh and Way. The advantage of the logistic regression model is that the dependent variable is a probability which it more comparable with the output of a BN. However, as previous discussed in section 3.1.2 it is difficult to determine what the relative importance of the Singh and Way variables is. One way to address this question is through the diagnosticity of the variables in the BN. Diagnosticity is the ability to distinguish among hypotheses. The greater the diagnosticity of a variable, the more useful it is in reducing the uncertainty about the hypothesis under investigation. In this case, the hypothesis under investigation is whether a country has acquired nuclear weapons.

The diagnosticity calculation based on the amount of potential entropy reduction as defined by Jensen [12]. Entropy is also known as Uncertainty in Shannon Information Theory [13] and is calculated as:

$$
\mathrm{U}(\mathrm{X})=-\sum_{i=1}^{n} p\left(x_{i}\right) \log _{2} p\left(x_{i}\right)
$$

Where $\mathrm{U}(\mathrm{X})$ is the entropy of the discrete random variable $\mathrm{X} . p\left(x_{i}\right)$ is the probability that $\mathrm{X}$ takes the value $x_{i}$.

The diagnostic value is the difference between the uncertainty of the prior distribution and the expectation of the uncertainty in the posterior distributions, where the expectation is uncertainty in the posterior distributions weighted by the "pre-posterior" distributions.

The diagnosticity of the predictors for the Acquire BN is shown in Table 3.2. The greater the diagnosticity of a predictor the larger the impact it will have in deciding whether a State is acquiring nuclear weapons. Variables with the highest diagnostic value are the most helpful in deciding among the competing hypotheses (acquiring or not) because they will have the greatest impact on reducing the uncertainty. In practice, actual choice of which variables are used to obtain information will depend on the availability of the data and data collection costs. The tables shows the predictive variables listed in order of their diagnostic value which was calculated given no prior information. 


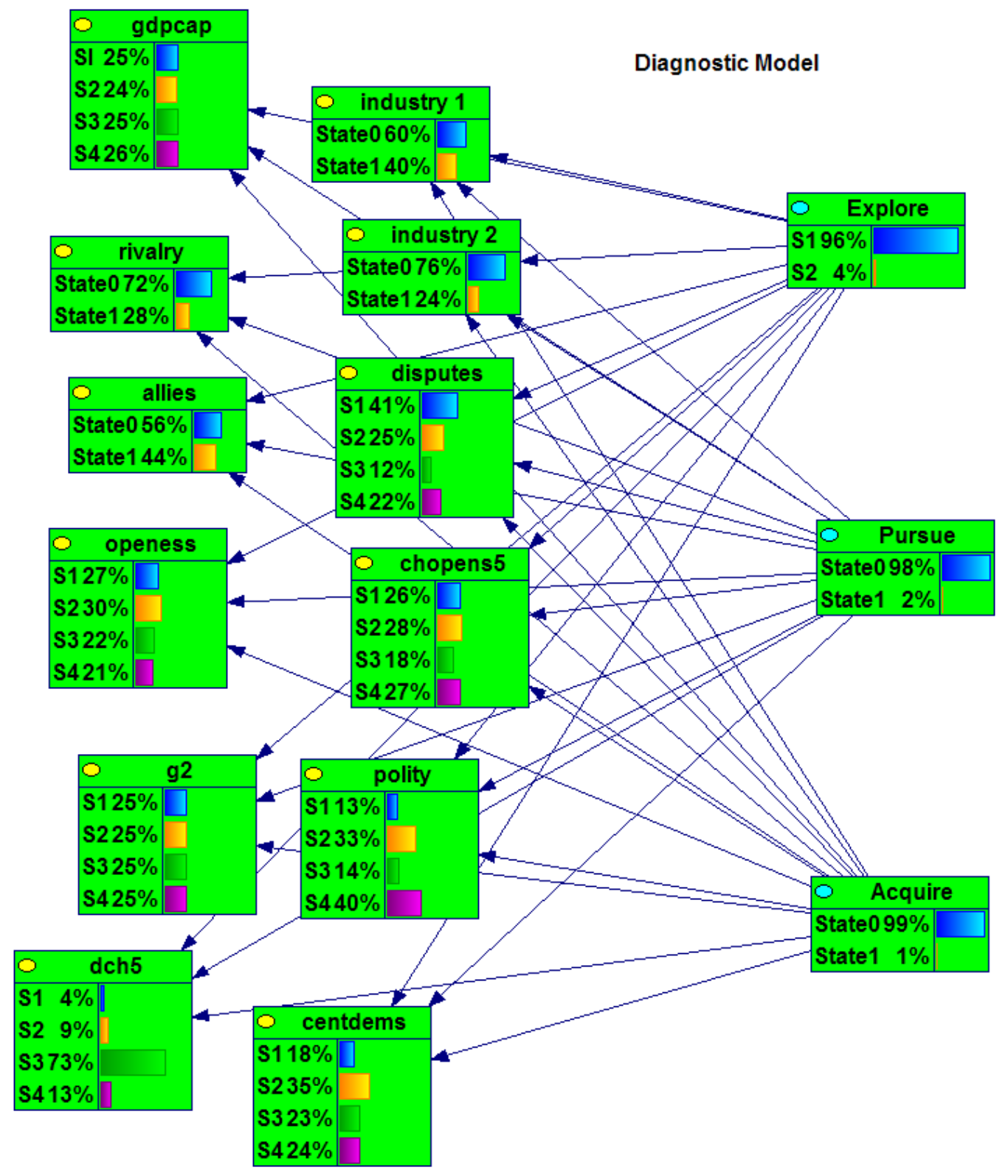

Figure 3.2. BN Constructed using Singh and Way Dataset

\subsubsection{Using Quantitative Analysis of Singh Data to Enhance GIF Model}

The team considered the merits of enhancing GIF PR\&PP model metrics versus augmenting them with social factors and the team chose the enhancement option as being easier to initially implement. Enhancement of the GIF metrics is the strategy of not substantially altering the collection of metrics, but to make their estimates more accurate by a fuller consideration of information, primarily social, that is relevant to an estimate of their values. Augmentation of the GIF metrics is the strategy of adding additional metrics so the estimates of PR would be more comprehensive by consideration of additional factors, primarily social, that would increase the accuracy of the estimates. It was thought that it might be easier, both from a methodological perspective and the perspective of gaining acceptance by the GIF 
PR\&PP working group, to incorporate social factors into the existing metrics rather than append the list of metrics with social considerations.

Figure 3.3 shows the two sets of metrics and a preliminary assessment of the relationships between the Singh and Way variables to the GIF metrics Also, it points out the need for a modeling option that could be further developed. The Singh and Way predictor variables are listed in order of diagnostic value in determining whether a country is likely to acquire nuclear weapons. The ones shown in yellow are thought to be relevant to GIF metrics. The solid arrows point to the most relevant metric; the dotted arrows are secondary and have less direct relevance. The variables shown in orange are ones for which the connection seems tenuous.

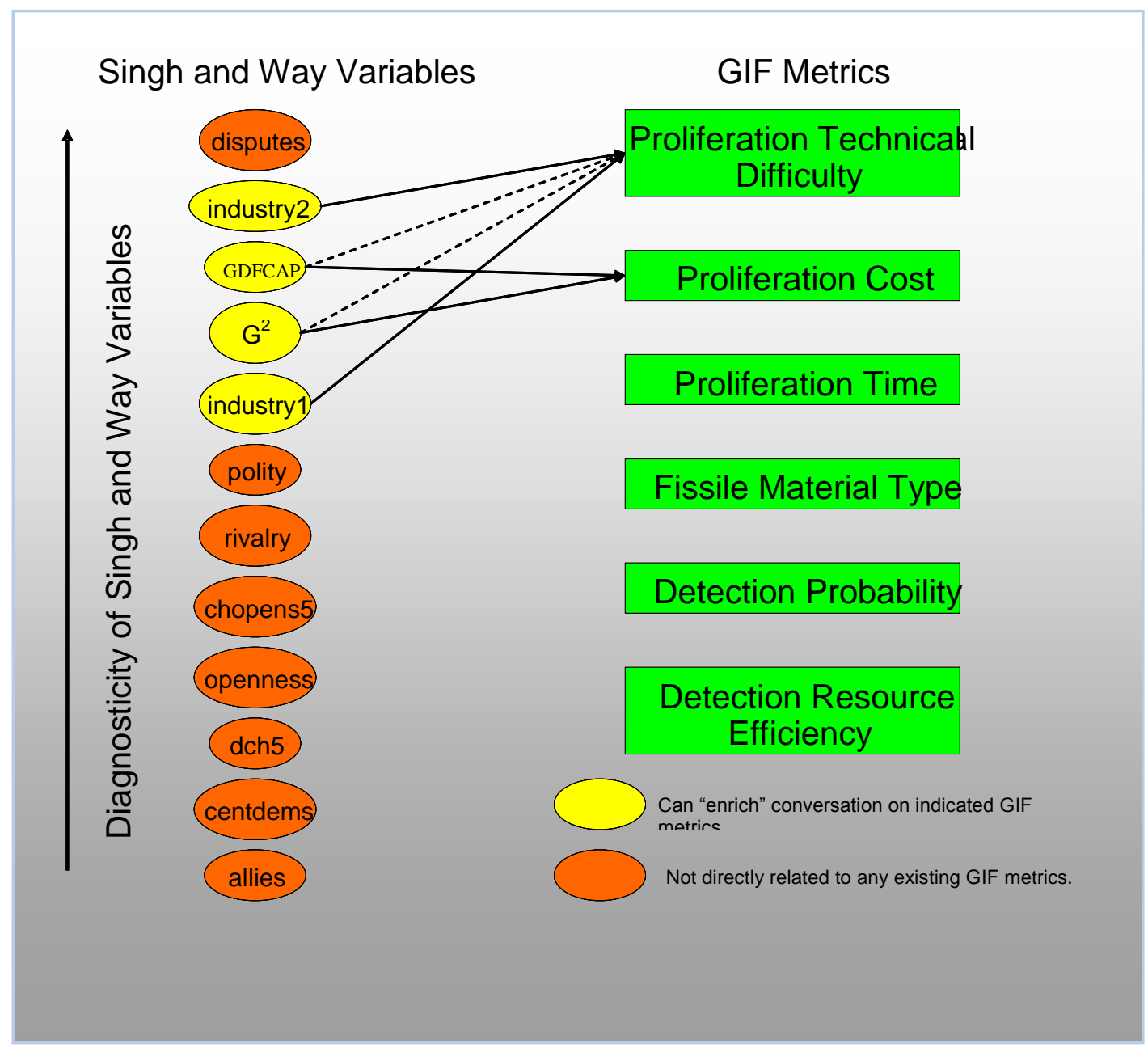

Figure 3.3. Tentative Relationship between Singh and Way Predictor Variables and Diagnosticity

The relationship of the Singh and Way variables to the GIF metrics is not straightforward for many of the variables as they were chosen for very different purposes. The Singh and Way variables were developed to predict whether a nation would proliferate by exploring, pursuing, or acquiring nuclear weapons. As previously discussed, the variables fall into categories of: technical expertise, financial resources, and political measures, primarily of regional stability and harmony of relationships with other countries, but also measures of democracy and openness within the nation. The GIF metrics were developed to measure the PR of a specific technology. They focus on technical difficulty, cost, time, 
detection probability, fissile material type, and detection resource efficiency. Detection resource efficiency refers to how expensive it is to apply and verify safeguards at a given facility. For example, standard Pressurized Water Reactors (PWRs) are fairly easy to safeguard, but reactors like the Example Sodium Fast Reactor (ESFR) ${ }^{1}$ [15], which involve a loss of continuity of knowledge of the fuel while in the core due to our inability to see the fuel or get cameras to work in liquid sodium, has made that reactor much harder (and perhaps more expensive) to safeguard.

Given the disparity between the two sets, it is probably worth exploring the strategy of including some purely social metrics as additions to the current set of GIF metrics. These metrics could enhance the existing GIF metrics with Singh and Way variables. Which of the variables used by Singh and Way are useful needs to be determined empirically by working with researchers that currently use the GIF metrics. The most obvious choice of additional social variables would be those dealing with conflict and rivalry, which would incorporate information from disputes, rivalry, and allies. This would measure the propensity of the destination country to be motivated to proliferate. Countries with little or no propensity to proliferate would then be trusted with less proliferation-resistant technologies than countries with a high motivation to proliferate. A second possible candidate metric would be related to the internal politics of the country and to what extent it was an open democracy. Relevant Singh and Way variables for this metric are polity, chopens5, openness, dch5, and centdems. These variables have considerably less diagnostic value than those related to conflict and rivalry, so we may want to focus just on these initially. A better case can be made for adding a metric that has a strong potential impact.

In addition to using the Singh and Way variables to improve the GIF metrics, one should also explore other social metrics. The Singh and Way metrics focus on a country's tendency to proliferate. It could be that the relevant social metrics are more directly related to the specific processes involved in proliferation. From a social perspective, how difficult is it to proliferate using a given technology? Relevant factors may come from the fields of organizational psychology or industrial engineering. These types of social variables have not been considered heretofore. The Singh and Way variables are the ones that have had the most currency in the literature. But as stated before, that may not be the most relevant literature. Exploring what makes it difficult to proliferate from the perspective of overcoming the social and organizational difficulties inherent in all working groups is a potential line of research that may prove fruitful.

\subsubsection{Future BN Model Development and Quantitative Analysis}

The BN model using the Singh and Way dataset is a preliminary model in the earliest stage of development. We relied on the structure developed in Singh and Way's work and are confident that the structure is consistent with the literature on proliferation since the variables included in their study are found throughout the literature. However, we envision a larger, more comprehensive model that would make use of the Singh and Way dataset and the Jo and Gartzke dataset [16], modeling presented in this project's earlier report [17], and other models and datasets to be identified and/or developed.

The virtues of BNs models for analysis and exploration are as follows:

- They are easy to run cases specific to a particular country,

\footnotetext{
${ }^{1}$ The ESFR is a hypothetical reactor designed to test proliferation resistance and physical security assessment approaches developed by the GIF PR\&PP working group.
} 
- Readily available software ${ }^{2}$ displays the models and supports direct interaction with the models.

- Software calculates diagnostic information indicating importance of model components;

- They can combine variables from several models;

- They can make use of datasets supplemented with expert judgment where data is not available;

In addition to combining the Singh and Way model with other models, there are a number of avenues in which Singh and Way dataset can be further explored.

There were two technical challenges that are important to address in using the Sigh and Way dataset: 1) how to treat missing data and 2) how to address the time aspect of the Singh Way proliferation data. With regard to the time aspect, the dependent variables in the Singh and Way dataset are "explore", "pursue", and "acquire", which represent the three stages of nuclear proliferation. In the dataset they are coded as zero as long as those actions did not occur in a given year; in the year that they do occur they are coded as a 1, and the coding for subsequent years is N/A. The authors try to capture the transition of the proliferation stages using a hazard regression model. This raises a question on how to use this dataset to "learn" parameter values in a BN. Should we build a BN that is sensitive enough to detect these transition points or would we be doing well enough to be able to classify countries as either a proliferator or a nonproliferator? Currently this project's modeling focus is not on the transition points. This raises a question of whether we should be using a subset of the dataset and/or modifying it prior to using it to learn the probabilities in the BN. The BN software that we used is GeNIe ${ }^{3}$. While GeNIe uses the Expectation Maximization (EM) algorithm [18], it is not entirely clear how it deals with missing data. GeNIe does give the option of replacing missing values, either with a specific number or with the average of the data in the column. The existing BN "learned" the parameters by treating all the N/A entries as missing data. However, when one chooses to leave the NA values as blank, it is not clear how GeNIe deals with it. On the other hand, one could justify replacing all the N/As with 1s, arguing that whatever conditions caused the country to acquire nuclear weapons would also be in effect as long as they continued to keep them. Or at least whatever the conditions are, if they are such that the country continues to keep nuclear weapons once they have acquired them, then these conditions should be part of the data used to learn the parameters. This will result in multiple entries that may be very similar or the same. A similar situation arose for one of the authors (Brothers) when learning BN parameters from the Minorities at Risk (MAR) dataset and the statistician on the project, who was developing another learning algorithm made the decision to use duplicate rows. So, there is a precedent in using multiple rows that may be the same or similar across years. Eliminating these rows would require that one also eliminates the rows in which there are duplicate zeros in order to be consistent. Future research could explore having the BN learn the parameters with several different subsets of the data and investigate the differences among the updated BNs and their relative ability to correctly distinguish between proliferators and nonproliferators.

Currently there are four variations of the preliminary BN that the project team has built using the Singh and Way dataset. The version shown in Figure 3.2 has three "dependent" variables or hypotheses: Explore, Pursue, and Acquire. There are also three other BNs, each testing the hypothesis of Explore,

${ }^{3}$ http://genie.sis.pitt.edu/

Decision Systems Laboratory, University of Pittsburgh 
Pursue or Acquire, respectively. One could also build a version in which the three possible states of Explore, Pursue, and Acquire are combined into a single variable. This variable might have five states: None, Explore, Pursue, Acquire, and Acquired. This model would assume that each of these states is mutually exclusive and would provide the probability distribution over the five possibilities, which is consistent with the structure of the Singh and Way dataset.

In addition to building different versions of BNs using the Singh and Way dataset, it is also useful to compare the results of the Singh and Way regression models to the BNs built using their dataset. Two key questions need to be examined. Does the regression model give the same probability for the dependent variable as the $\mathrm{BN}$ for identical cases? How can one assess the importance of the various predictor variables? We discuss each of these in turn in the following.

Do BN models give the same probabilities as Singh and Way's logistic regression model? The best way to test this is to pick country profiles and use the logistic regression equation to compute the probabilities and to compare the results with the corresponding probabilities calculated by the BNs. The value of each of the independent variables can be put directly into the logistic regression equation:

$$
P(X)=1 / \exp \left(B_{0}+B_{1} x_{1}+B_{2} x_{2}+\ldots\right)
$$

The resulting output is the probability of $\mathrm{X}$, where $\mathrm{X}$ is Explore, Pursue, or Acquire depending on the regression equation chosen. This number can be compared to the number calculated by the corresponding $\mathrm{BN}$ using the same country profile.

Determining the importance of the predictor variables in either of the two regression models cannot be done directly or with a high level of certitude. As Singh and Way point out, for their models, one cannot interpret the regression coefficients as the change in the dependent variable in relation to a unit change in the independent variable. For the hazard model, they offer both the standard coefficients and the coefficients in the log relative form. The latter can be interpreted in terms of the percentage increase in the value of the dependent variable, but the order in which the variables are regressed may affect the results. For the logistic regression, it is also the case that the regression coefficients are not directly interpretable. The authors provide significance tests whose p-values are an indication of the relative importance of the coefficients. However, there are two problems with using p-values to rank the importance of the independent variables. First, many coefficients have the same significance level; i.e., $\mathrm{p}=0.001$, and second, the order in which the independent variables are entered into the regression equation will affect their significance. Although it is possible to say which independent variables have a significant impact on the dependent variables, the relative magnitudes of these impacts are difficult to determine. Diagnosticity, as previously discussed, provides a way of measuring which variables are most useful in distinguishing among alternative hypotheses for a given state of knowledge. How to best compare this to the relative importance of the independent variables based on the Singh and Way regression models remains an open issue.

\subsection{Proposal for Enhancing the GIF Assessment Method}

The GIF approach to PR assessment uses pathway analysis to evaluate different scenarios in nuclear fuel-cycle facilities that could result in nuclear proliferation by a State [1]. A current application of the GIF methodology uses defined technical proliferation measures and incorporates structured expert elicitation while assessing five potential host-State proliferation strategies: concealed diversion, overt diversion, concealed facility misuse, overt facility misuse, and the use of an independent clandestine facility. In this approach the pathways are defined in accordance with the proliferation strategy and the target material. The pathway is broken down into three major stages: materials acquisition, materials 
processing, and weaponization. According to the methodology, the experts evaluate each pathway using six measures called Proliferation Pathway Measures. The first four measures evaluate intrinsic features of the system and the last two evaluate both intrinsic and extrinsic features. The measures are:

- Technical Difficulty (TD);

- Proliferation Cost (PC);

- Proliferation Time (PT);

- Fissile Material Type (MT);

- Detection Probability (DP); and

- Detection Resource Efficiency (DE).

The GIF approach and other technical PR assessments have historically focused on the following question: "What is the PR of NES Y?" We believe that the enhanced GIF model is able to explore more specific questions like: "What is the PR of NES Y when it is operating in the environment of NES Y?"; and "Do social factors affect the "technical PR of NES Y"?

In the current expert elicitation application of the GIF methodology, experts' opinions are elicited for each PR measure, relying on assumptions about the host-State threat as defined in the threat characterization. The threat characterization encompasses the motives of the host State to acquire nuclear weapons, as well as the time frame, the available resources, and the quantity of weapons sought. The experts use the threat characterization to put the proliferation pathway into a contextual setting. For example, the proliferation time of a given pathway may depend on how many weapons the State is seeking to develop from that pathway. Or, the proliferation technical difficulty for the pathway may depend on how technically advanced the State is. This State-level information is defined in the threat characterization, which is provided to the experts as part of the assessment.

So far, the GIF PR\&PP team has primarily exercised just one threat characterization, referred to here as the "base-case" threat characterization. The base case is meant to represent the important technical and social information needed to complete the PR assessment, and corresponds with a moderately developed State similar to some States currently considering the acquisition of nuclear energy for the first time. Because the base case is limited in scope and does not cover a broad range of threats, as recommended by the GIF working group, this report proposes the expansion and diversification of information in the threat characterizations to build a reference threat set based on social modeling. Figure 3.4 below illustrates the importance of being able to evaluate both the technical PR of a technology and an entity's propensity to proliferate in a combined analysis. It builds an inclusive index score to determine the actual proliferation threat to a specific piece of technology operating in a given environment. The PR of a technology ( $\mathrm{x}-$ axis), as illustrated in the figure, is not independent of the environment (y-axis) in which the technology is deployed. 


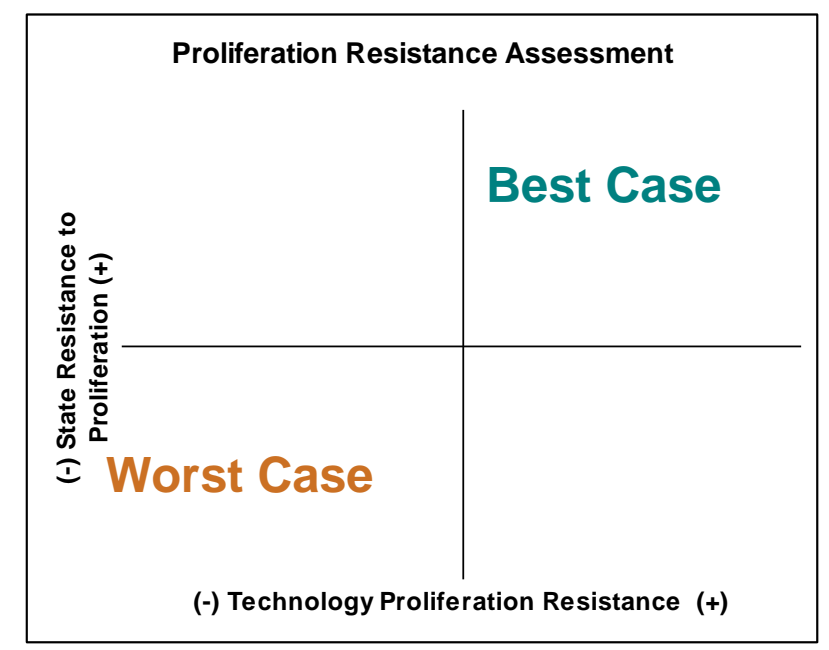

Figure 3.4. Social Versus Technical Resistance to Proliferation

From the preliminary analysis used a BN model based on the dataset from Singh and Way, seven social factors were identified as being the most important for predicting a State acquisition of a nuclear weapon. Those factors were:

- Industry 2: Measures whether energy, electricity, and steel production and consumption is above a threshold level. Supplements Industry 1 with aggregate and per-capita data on energy consumption, electricity production and generating capacity, and steel production.

- Disputes: 5-year moving average of the number of militarized interstate disputes per year in which the State is involved.

- GDPCAP: GDP per capita. The value of all final goods and services produced within a nation in a given year divided by the average population for the same year. Provides an indicator of economic development, which is closely linked to sophisticated technical, engineering, and manufacturing knowledge.

- G2: GDP squared. Indicates the size of the overall economy. The value was squared to account for the fact that the relationship between GDP and nuclear weapons production is not linear because weapons production occurs in an "economy of scale."

- Industry1: Measure of level of industrial capability based on electricity generation and domestic steel production.

- Polity: Democracy or autocracy level per country in a given year.

- Rivalry: Participation in an enduring rivalry, used to indicate a substantial and ongoing security threat (True or False for every year)

To utilize the social factors identified by the preliminary BN analysis, each social factor was broken into its "variable states" with an explanation of what that variable state means for each country, and a list of representative countries that were classified in each of these variable states in 2000. Table 3.3 shows the social factors, their descriptors, and examples of countries that fit within each variable state in the year 
2000 (according to the Singh and Way dataset). To integrate the social factors into the threat characterizations, the description from the "Explanation of Variable State" was inserted into the base-case threat characterization.

Table 3.3. Social Factors Defined by the BN Analysis with Descriptions and Example Countries (2000)

\begin{tabular}{|c|c|c|c|c|}
\hline \multirow[b]{2}{*}{ Indicator } & \multirow[b]{2}{*}{ State } & \multicolumn{3}{|c|}{ Explanation of Variable } \\
\hline & & Definition & State & Example Country \\
\hline \multicolumn{5}{|l|}{ Base } \\
\hline \multirow[t]{2}{*}{ Industry 2} & True & $\begin{array}{l}\text { Country meets threshold } \\
\text { for domestic energy, } \\
\text { electricity, and steel } \\
\text { production on a per-capita } \\
\text { and aggregate basis }\end{array}$ & $\begin{array}{l}\text { Country has high domestic } \\
\text { energy, electricity, and } \\
\text { steel production on a per- } \\
\text { capita and aggregate basis. } \\
\text { Represents the most } \\
\text { industrially developed } \\
\text { countries, generally with } \\
\text { large population bases. }\end{array}$ & $\begin{array}{l}\text { Canada, Argentina, Spain, } \\
\text { Ukraine, Nigeria, Pakistan, } \\
\text { Taiwan }\end{array}$ \\
\hline & False & $\begin{array}{l}\text { Country does not meet } \\
\text { threshold for domestic } \\
\text { energy, electricity, and } \\
\text { steel production on a per- } \\
\text { capita and aggregate basis }\end{array}$ & $\begin{array}{l}\text { Country has relatively low } \\
\text { domestic energy, } \\
\text { electricity, and steel } \\
\text { production on a per-capita } \\
\text { or aggregate basis. }\end{array}$ & $\begin{array}{l}\text { Belize, Jordan, United } \\
\text { Arab Emirates, Costa Rica, } \\
\text { Suriname, Ireland, Croatia, } \\
\text { Senegal, Uganda }\end{array}$ \\
\hline \multirow[t]{4}{*}{ Disputes } & 1 & $0-0.01$ & $\begin{array}{l}\text { Country had, on average, } \\
\text { no disputes in the past } 5 \\
\text { years. }\end{array}$ & $\begin{array}{l}\text { Panama, Tunisia, Nepal, } \\
\text { Malaysia }\end{array}$ \\
\hline & 2 & $0.01-1.01$ & $\begin{array}{l}\text { Country had, on average, } \\
\text { one dispute in the past } 5 \\
\text { years. }\end{array}$ & $\begin{array}{l}\text { Armenia, Sweden, } \\
\text { Rwanda, Egypt }\end{array}$ \\
\hline & 3 & $1.01-2.01$ & $\begin{array}{l}\text { Country had, on average, } \\
\text { one to two disputes in the } \\
\text { past } 5 \text { years. }\end{array}$ & China, Venezuela, Kuwait \\
\hline & 4 & $2.01-20$ & $\begin{array}{l}\text { Country had, on average, } \\
\text { between } 2 \text { and } 20 \\
\text { international disputes in } \\
\text { the past } 5 \text { years. }\end{array}$ & $\begin{array}{l}\text { United States, Russia, Iraq, } \\
\text { Japan, Turkey }\end{array}$ \\
\hline
\end{tabular}

Table 3.3. (contd)

\begin{tabular}{|c|c|c|c|c|}
\hline Indicator & State & Definition & $\begin{array}{l}\text { Explanation of } \\
\text { Variable State }\end{array}$ & Example Country \\
\hline \multirow[t]{4}{*}{ Gdpcap } & 1 & $0-1,500$ & $\begin{array}{l}\text { Country has among the } \\
\text { lowest GDP per capita in } \\
\text { the world. }\end{array}$ & Tanzania, Ethiopia, Kenya \\
\hline & 2 & $1,500-3,500$ & $\begin{array}{l}\text { Country has a mid-range } \\
\left(25^{\text {th }}-50^{\text {th }} \text { percentile }\right) \\
\text { GDP per capita. }\end{array}$ & Congo, Philippines, Kenya \\
\hline & 3 & $3,500-7,600$ & $\begin{array}{l}\text { Country has a mid-range } \\
\text { GDP }\left(50^{\text {th }}-75^{\text {th }} \text { percentile }\right) \\
\text { per capita. }\end{array}$ & $\begin{array}{l}\text { Uzbekistan, Fiji, Thailand, } \\
\text { Morocco }\end{array}$ \\
\hline & 4 & $7,600-50,000$ & $\begin{array}{l}\text { Country has among the } \\
\text { highest GDP per capita in } \\
\text { the world. }\end{array}$ & $\begin{array}{l}\text { Japan, Taiwan, Sudan, } \\
\text { Denmark, Belarus, } \\
\text { Slovakia, France, Chile }\end{array}$ \\
\hline
\end{tabular}




\begin{tabular}{|c|c|c|c|c|}
\hline Indicator & State & Definition & $\begin{array}{l}\text { Explanation of } \\
\text { Variable State }\end{array}$ & Example Country \\
\hline \multirow[t]{4}{*}{ G2 } & 1 & $0-2.2 \mathrm{E}+06$ & $\begin{array}{l}\text { Country has one of the } \\
\text { smallest }\left(1^{\text {st }}-25^{\text {th }}\right. \\
\text { percentile) economies in } \\
\text { the world. }\end{array}$ & Uganda, Ethiopia, Laos \\
\hline & 2 & $2.2 \mathrm{E}+06-1.3 \mathrm{E}+07$ & $\begin{array}{l}\text { Country has a mid-small } \\
\text { economy }\left(26^{\text {th }}-50^{\text {th }}\right. \\
\text { percentile }) \text {. }\end{array}$ & $\begin{array}{l}\text { Haiti, Bangladesh, } \\
\text { Turkmenistan }\end{array}$ \\
\hline & 3 & $1.3 \mathrm{E}+07-6.0 \mathrm{E}+07$ & $\begin{array}{l}\text { Country has mid-large } \\
\text { economy }\left(51^{\text {st }-} 75^{\text {th }}\right. \\
\text { percentile }) \text {. }\end{array}$ & $\begin{array}{l}\text { Guatemala, Yugoslavia, } \\
\text { Libya, Thailand }\end{array}$ \\
\hline & 4 & $6.0 \mathrm{E}+07-2.0 \mathrm{E}+09$ & $\begin{array}{l}\text { Country has one of the } \\
\text { largest }\left(76^{\text {th }}-99.9^{\text {th }}\right. \\
\text { percentile) economies in } \\
\text { the world. }\end{array}$ & $\begin{array}{l}\text { Singapore, Oman, Israel, } \\
\text { UK }\end{array}$ \\
\hline \multirow[t]{2}{*}{ Industry 1} & True & $\begin{array}{l}\text { Country produces steel and } \\
\text { at least } 5000 \mathrm{MW} \text { of } \\
\text { electricity }\end{array}$ & $\begin{array}{l}\text { Country has domestic steel } \\
\text { production and produces at } \\
\text { least } 5000 \mathrm{MW} \text { of } \\
\text { electricity. }\end{array}$ & $\begin{array}{l}\text { Qatar, South Africa, } \\
\text { Bosnia, Finland, USA, } \\
\text { Cuba }\end{array}$ \\
\hline & False & $\begin{array}{l}\text { Country does not produce } \\
\text { steel or at least } 5000 \mathrm{MW} \\
\text { of electricity }\end{array}$ & $\begin{array}{l}\text { Country does not have } \\
\text { domestic steel production, } \\
\text { or does not produce at least } \\
5000 \text { MW of electricity, or } \\
\text { both. }\end{array}$ & $\begin{array}{l}\text { Nicaragua, Estonia, Chad, } \\
\text { United Arab Emirates }\end{array}$ \\
\hline \multirow[t]{4}{*}{ Polity } & 1 & $-(-10)-(-7)$ & $\begin{array}{l}\text { Country is highly } \\
\text { autocratic. }\end{array}$ & $\begin{array}{l}\text { Swaziland, Bhutan, Laos, } \\
\text { Oman }\end{array}$ \\
\hline & 2 & $(-7)-(-3)$ & $\begin{array}{l}\text { Country is slightly } \\
\text { autocratic. }\end{array}$ & $\begin{array}{l}\text { Egypt, Pakistan, Eritrea, } \\
\text { Gambia, Rwanda }\end{array}$ \\
\hline & 3 & $(-3)-8$ & $\begin{array}{l}\text { Country is slightly } \\
\text { democratic. }\end{array}$ & $\begin{array}{l}\text { Mexico, Russia, Haiti, } \\
\text { Djibouti }\end{array}$ \\
\hline & 4 & $8-10$ & $\begin{array}{l}\text { Country is highly } \\
\text { democratic. }\end{array}$ & $\begin{array}{l}\text { Greece, Poland, Uruguay, } \\
\text { Iceland, Slovakia, Belgium }\end{array}$ \\
\hline \multirow[t]{2}{*}{ Rivalry } & True & $\begin{array}{l}\text { Country has enduring } \\
\text { rivalry }\end{array}$ & $\begin{array}{l}\text { Country has at least one } \\
\text { enduring rivalry. }\end{array}$ & $\begin{array}{l}\text { Peru, Somalia, Algeria, } \\
\text { Kenya, India, Cambodia }\end{array}$ \\
\hline & False & $\begin{array}{l}\text { Country does not had an } \\
\text { enduring rivalry }\end{array}$ & $\begin{array}{l}\text { Country has no enduring } \\
\text { rivalries. }\end{array}$ & $\begin{array}{l}\text { Egypt, Malaysia, } \\
\text { Singapore, Burma }\end{array}$ \\
\hline
\end{tabular}

Three threat characterizations were developed from the factors presented above:

- A high case: all social factors correspond to variable states for which it is the most likely for a country to acquire nuclear weapons.

- A low case: all social factors correspond to variable states for which is least likely for a country to acquire nuclear weapons.

- A moderate case: some social factors are in the "middle" range for likelihood to develop a nuclear weapon, social factors correspond to a combination of most likely and least likely variable states.

The three cases were added to the existing base threat characterization that is provided to experts during the GIF PR assessments. Some of the social factors identified in the BN modeling activity conflicted with the social factors identified in the existing base-case threat characterization, so the basecase was modified as necessary. The base-case threat characterization, and the high, medium, and low cases are presented below with the differences between the cases highlighted in bold. 


\section{$\underline{\text { Base Case }}$}

The host State is a Non-Nuclear Weapons State (NNWS) with a national plan to introduce nuclear power in the near term. The State is apparently fully committed to its nonproliferation obligations, is a signatory to the NPT, and has the Additional Protocol (AP) in force.

The State has experience in operating several research reactors but not power reactors. It has limited nuclear fuel-cycle capabilities. The State has no declared indigenous enrichment or reprocessing capability but has a limited ability to fabricate fuel, produce isotopes (including chemical separations knowhow and experience), and handle radioactive waste. The State's industrial infrastructure is able to support the nuclear industry through development of nuclear technology, provide training for experts in the field, and manufacture basic nuclear equipment components.

A State agency or a nongovernment commercial organization will operate the reactor under the regulatory framework of the host country for safety and security. The State has determined to produce nuclear weapons and intends to acquire at least one significant quantity (SQ) of weapons-usable material in $1-10$ years.

\section{$\underline{\text { High Case }}$}

The host State is an NNWS with a national plan to introduce nuclear power in the near term. The State's government system includes the presence of institutions and procedures through which citizens can express effective preferences about alternative policies and leaders, the existence of institutionalized constraints on the exercise of power by the chief executive, and a guarantee of civil liberties to all citizens in their daily lives and in acts of political participation. The State is apparently fully committed to its nonproliferation obligations, is a signatory to the NPT, and has the AP in force. The State has among the highest GDP per capita in the world, as well as one of the largest overall economies in the world. The host State had, on average, at least two militarized international disputes in the past 5 years, and has at least one enduring rivalry.

The State has experience in operating several research reactors but not power reactors. It has limited nuclear fuel-cycle capabilities. The State has no declared indigenous enrichment or reprocessing capability but has a limited ability to fabricate fuel, produce isotopes (including chemical separations knowhow and experience), and handle radioactive waste. The State has high domestic energy, electricity, and steel production on a per-capita and aggregate basis, and represents the most industrially developed countries. The State domestically produces steel and at least $5000 \mathrm{MW}$ of electricity.

A State agency or a nongovernment commercial organization will operate the reactor under the regulatory framework of the host country for safety and security. The State has determined it will produce nuclear weapons and intends to acquire at least one SQ of weapons-usable material in 1-10 years.

\section{Moderate Case}

The host State is an NNWS with a national plan to introduce nuclear power in the near term. The State's government system includes some institutions and procedures through which citizens can express effective preferences about alternative policies and leaders, yet the selection of executives 
tends to be among the political elite. Though there are some institutional constraints on the exercise of executive power, those restraints are not widely enforced. The State is apparently fully committed to its nonproliferation obligations, is a signatory to the NPT, and has the AP in force. The State has a mid-range GDP, as well as an average-sized overall economy. The host State had, on average, one international dispute in the past 5 years, and has no enduring rivalries.

The State has experience in operating several research reactors but not power reactors. It has limited nuclear fuel-cycle capabilities. The State has no declared indigenous enrichment or reprocessing capability but has a limited ability to fabricate fuel, produce isotopes (including chemical separations knowhow and experience), and handle radioactive waste. The State's industrial infrastructure is able to support the nuclear industry through development of nuclear technology, provide training for experts in the field, and manufacture basic nuclear equipment components. The State has low domestic energy, electricity, and steel production on a per-capita and aggregate basis, and represents a moderately industrially developed country, generally with a small-to-moderate-population base. The State domestically produces steel and at least $5000 \mathrm{MW}$ of electricity.

A State agency or a nongovernment commercial organization will operate the reactor under the regulatory framework of the host country for safety and security. The State has determined to produce nuclear weapons and intends to acquire at least one SQ of weapons-usable material in 1-10 years

$\underline{\text { Low Case }}$

The host State is an NNWS with a national plan to introduce nuclear power in the near term. The State's government system includes a sharp restriction or suppression of competitive political participation, a regularized process of selection within the political elite for chief executives, and the exercise of executive power with few institutionalized constraints. The State is apparently fully committed to its nonproliferation obligations, is a signatory to the NPT, and has the AP in force. The State has among the lowest GDP per capita in the world, and one of the smallest overall economies in the world. The State had no militarized international disputes in the past 5 years, and has no enduring rivalries.

The State does not have previous experience operating a research reactor or power reactors. It has limited nuclear fuel-cycle capabilities. The State has no declared indigenous fuel fabrication, enrichment or reprocessing capability, but has limited capability to produce isotopes (including chemical separations knowhow and experience), and handle radioactive waste. The State has relatively low domestic energy, electricity, and steel production on a per-capita or aggregate basis and represents the least industrially developed countries. The State does not domestically produce steel and produces less than $5000 \mathrm{MW}$ of electricity.

A State agency or a nongovernment commercial organization will operate the reactor under the regulatory framework of the host country for safety and security. The State has determined it will produce nuclear weapons and intends to acquire at least one SQ of weapons-usable material in 1-10 years.

The high-, low-, and base-case scenarios were inserted into an expert questionnaire, and sent with two proliferation pathways for experts to evaluate for the PWR-1000 nuclear power reactor. The proliferation pathways and PWR-1000 reactor were used previously in proliferation pathway assessments and extensive background material was already available to the research team. 


\subsection{Engagement with the GIF PR\&PP}

An exercise and questionnaire was developed to determine whether the social factors identified by social modeling would have an impact on technical PR measures. The exercise and expert questionnaire was designed so that the experts would evaluate the six GIF PR\&PP measures for the proliferation pathways using the original threat characterization (the base case). Then the experts would be presented with the new threat characterizations and would be asked whether, given the new threat characterizations, the PR results for that proliferation pathway would differ from the results indicated for the base case. If they were different, how much did they change? For brevity, and because the original threat characterization used for the expert elicitation resembled a "moderate" case, the experts would only be presented with the base, high, and low cases.

The questionnaire will be distributed to experts in the PR field who have previously participated in expert elicitations on the GIF proliferation pathway assessment methodology. The questionnaire incorporates proliferation pathways that the experts have evaluated before to reduce the burden of familiarization with a new NES.

A description of the proposed exercise and expert questionnaire is presented in Appendix B.

The results from the questionnaire would be captured by filling out Tables 3.4 and 3.5.

Table 3.4. Expert Questionnaire Form - Diversion Pathway

\begin{tabular}{lccc}
\hline \multicolumn{1}{c}{ PR Measure } & $\begin{array}{c}\text { Average Result for } \\
\text { Base Case }\end{array}$ & $\begin{array}{c}\text { Average Result for } \\
\text { High Case }\end{array}$ & $\begin{array}{c}\text { Average Result for } \\
\text { Low Case }\end{array}$ \\
\hline Proliferation Time & & & \\
Proliferation Cost & & \\
Proliferation Technical Difficulty & & \\
Fissile Material Type & & \\
Detection Probability & & \\
Detection Resource Efficiency & & \\
\hline
\end{tabular}

Table 3.5. Results from Expert Questionnaire - Misuse Pathway

\begin{tabular}{|c|c|c|c|}
\hline PR Measure & $\begin{array}{c}\text { Average Result for } \\
\text { Base Case }\end{array}$ & $\begin{array}{c}\text { Average Result for } \\
\text { High Case }\end{array}$ & $\begin{array}{l}\text { Average Result for } \\
\text { Low Case }\end{array}$ \\
\hline \multicolumn{4}{|l|}{ Proliferation Time } \\
\hline \multicolumn{4}{|l|}{ Proliferation Cost } \\
\hline \multicolumn{4}{|l|}{ Proliferation Technical Difficulty } \\
\hline \multicolumn{4}{|l|}{ Fissile Material Type } \\
\hline \multicolumn{4}{|l|}{ Detection Probability } \\
\hline Detection Resource Efficiency & & & \\
\hline
\end{tabular}

Results will be examined to see if there is a difference between the base case threat scenario and the two new threat scenarios that incorporated social information. It may also be possible to determine if there was a difference between the high and low case threat scenarios. 


\subsection{User Framework for Enhanced GIF Model}

This section discusses implementation in a user framework for the enhanced GIF (Generation IV International Forum PR\&PP) model. It discusses the potential users of the model, how users would interface with the model, and how updates might be incorporated into the model.

\subsection{Users}

PR information is valuable to a broad range of experts and decision-makers. According to Pomeroy, these users include:

1) nuclear energy policy decision-makers;

2) national licensing and regulatory authorities and export control authorities;

3) national, regional, and international safeguards inspectorates;

4) industrial designers, producers, and vendors; and

5) utility owners and operators [1].

These five user groups and the potential value gained by them from doing PR assessments are illustrated in Table 4.1. Groups 1, 2, and 3 may benefit the most from an enhanced PR assessment methodology. Policy maker or implementers must take social factors into consideration, to some extent, when developing or implementing policy. Whereas, designers, producers, utility owners and operators are more apt to just abide by whatever policies and/or regulations apply to them.

Table 4.1. Users and Uses (from Pomeroy [1])

\begin{tabular}{|c|c|}
\hline $\begin{array}{c}\text { Potential Users of a PR Assessment and Evaluation } \\
\text { Methodology }\end{array}$ & Illustrative Uses of PR Information \\
\hline $\begin{array}{l}\text { 1. Government officials, including Energy Ministry } \\
\text { officials, Foreign Ministry Officials, and Legislative } \\
\text { officials responsible for program approvals and } \\
\text { funding appropriations }\end{array}$ & $\begin{array}{l}\text { a. Ensuring provision of sustainable energy supply } \\
\text { from safe, secure, economic, and proliferation- } \\
\text { resistant sources } \\
\text { b. Basing nuclear export control decisions on well- } \\
\text { understood and assessed proliferation threats }\end{array}$ \\
\hline $\begin{array}{l}\text { 2. National licensing and regulatory authorities and } \\
\text { export control authorities for State exports, State } \\
\text { imports, and indigenous development }\end{array}$ & $\begin{array}{l}\text { a. Developing guidance on and validation of effective } \\
\text { and efficient implementation of PR/safeguards } \\
\text { requirements in design and operation } \\
\text { b. Providing basis for cooperation with regional and } \\
\text { international safeguards authorities }\end{array}$ \\
\hline $\begin{array}{l}\text { 3. National, regional, and international safeguards } \\
\text { inspectorates }\end{array}$ & $\begin{array}{l}\text { a. Providing understanding of the role of safeguards } \\
\text { measures in PR } \\
\text { b. Ensuring that facility design and operation facilitate } \\
\text { the implementation of safeguards }\end{array}$ \\
\hline 4. Industrial designers/producers/vendors & $\begin{array}{l}\text { a. Employing usable guidance for effective and } \\
\text { efficient implementation of } \mathrm{PR} / \mathrm{safeguards} \\
\text { requirements in design and operation } \\
\text { b. Ensuring that there are transparent acceptance }\end{array}$ \\
\hline
\end{tabular}


procedures with assessable cost impacts

5. Utility owners and operators

a. Enhancing public acceptance of nuclear energy production

b. Providing transparent means for demonstrating that perceived threats are adequately controlled

c. Optimizing extrinsic and intrinsic PR measures with facility safety, operations, and cost

\subsection{User Interface}

The GIF proliferation assessment is currently exercised as an expert elicitation-informed process. Experts are guided through an elicitation process to determine the plausibility of concealed diversion, undeclared production, or potential misuse of a declared facility based on either a given or developed threat characterization on a particular facility configuration. The explicit actions that a proliferator might choose to divert material, or misuse and divert material are regarded as a diversion pathway. The proliferation assessment process tries to identify the different possible pathways a proliferator might take. This consists of the following steps:

- Evaluate the forms and quantity of potential target material in the facility.

- Identify the possible physical mechanisms that could be used to remove the material.

- Identify the physical design barriers to removal of material.

- Identify the safeguard barriers that protect each physical mechanism.

- Hypothesize ways to defeat the safeguards.

- Lay out (define) pathways (scenarios) for potential removal of each target.

- For each pathway record, elicit the expert's opinion about how much the scenario contributes (high to low) to each of the six proliferation measures.

Each of these steps is performed in the context of the type of proliferation threat at a given threat location. As discussed in Section 3.2, the project team proposes a reference threat set to meet the requirements of GIF. This reference threat set would utilize social factors to inform assumptions about the country where an NES would reside. This reference threat set provides the experts with additional information that does not require extensive modification of the existing tools. The existing tool is software that guides experts through a structured elicitation process and provides a means of documenting the process and results. As a result, the user interface to the enhanced version of the GIF proliferation assessment is unchanged in the expert elicitation application of the assessment approach. The only change is that the assumptions about the specific threat under consideration would include the social factors determined by our model to be important. This allows experts to judge the pathway in the context of a slightly more complex and well-specified threat than they currently use by adding social factors.

In an effort to determine the impact of these social factors and a more specified reference threat set on the GIF PR assessment methodology, the project team is engaging the GIF PR\&PP working group in a test of this enhancement concept. The survey methodology discussed in Section 3.2 will be utilized to test the effect of this reference threat set on the expert elicitation process. The test will measure the 
impact of these reference threats against the existing, generalized threat utilized by the experts for their assessments. The test will also measure the impact that variance in the reference threats have against one another. It will attempt to determine, whether there is any relationship between the impacts of threats determined by the BN model and the experts' judgments about the PR of the NES. We are also interested in how and why the expert's judgment was impacted. With these results, the project team hopes to refine the GIF assessment approach and also make improvements to the BN models.

In an effort to keep the reference threat set updated, the social factors would be updated as better quantitative models are developed and the relative importance of the factors is better understood. It is this project's intention to further develop proliferation models, which will help inform the reference threat set. Currently the dataset has no information past the year 2000 and a great deal of proliferation activity has occurred since then. It is possible that the results of the model could be affected as more data become available and new cases are incorporated into our analysis. 



\subsection{Conclusion}

We built the BNs to leverage their analytical capability with future ambitions in mind. We used the Singh and Way dataset to develop a preliminary BN model for predicting proliferation likelihood. We compared the results of the BN models to results of the regression models used by Singh and Way. Although Singh and Way identify which independent variables are significant in predicting proliferation, the type of regression models used make it is difficult to determine the relative importance of the predictor variables. We addressed the question of relative importance using the $\mathrm{BN}$ and the concept of diagnosticity. The research team identified variables determined to have the highest diagnostic value using this preliminary model.

The characteristics of these variables were then used to develop a reference threat set to evaluate NESs against the threat associated with a specific location. The team is seeking to collaborate with the GIF PR\&PP working group to determine whether and to what degree the social factors identified by the social modeling have an impact on assessing an NES using the six GIF PR metrics

The BN model using Singh and Way data is a preliminary model However, we envision a larger, more comprehensive model that would make use of the Singh and Way dataset, other datasets such as the Jo and Gartzke dataset [1], and variables reported on in an earlier project report [2]. The virtues of BN models for analysis and exploration include:

- They are easy to run cases specific to a particular country,

- Readily available software ${ }^{1}$ displays the models and supports direct interaction with the models.

- Software calculates diagnostic information indicating importance of model components;

- They can combine variables from several models;

- They can make use of datasets supplemented with expert judgment where data is not available;

These virtues will be pursued in further research, which involves developing a State-level model and determining how to model multiple locations or facilities within a country. 



\subsection{References}

\section{From Chapter 1}

[1] PNNL-18438. 2009. Utility of Social Modeling for Proliferation Assessment - Preliminary Assessment. Pacific Northwest National Laboratory, Richland, Washington.

\section{From Chapter 2}

[1] PNNL-18438. 2009. Utility of Social Modeling for Proliferation Assessment-Preliminary Assessment. Pacific Northwest National Laboratory, Richland, Washington.

[2] Singh S and CR Way. 2004. "The Correlates of Nuclear Proliferation: A Quantitative Test." Journal of Conflict Resolution 48(6):859-885.

[3] Sagan S. 1997. "Why Do States Build Nuclear Weapons? Three Models in Search of a Bomb." International Security 21(3):54-86.

[4] Jo D-J and E Gartzke. 2007. "Determinants of Nuclear Weapons Proliferation." Journal of Conflict Resolution 51(1):167-194. Accessed March 24, 2009, at http://jcr.sagepub.com/cgi/content/abstract/51/1/167.

[5] Rublee M. 2008. "Taking Stock of the Nuclear Nonproliferation Regime: Using Social Psychology to Understand Regime Effectiveness.” International Studies Review 10(3):420-450. Accessed March 24, 2009, at http://www3.interscience.wiley.com/journal/121385697/abstract.

[6] Hymans J. 2006. The Psychology of Nuclear Proliferation: Identify, Emotions, and Foreign Policy. Cambridge University Press, Cambridge, Massachusetts. Accessed March 24, 2009, at http://books.google.com/books?hl=en\&lr=\&id=EoNoZom3TIwC\&oi=fnd\&pg=PA1\&dq=+The+Ps ychology+of+Nuclear+Proliferation:+Identify,+emotions,+and+Foreign+Policy,\&ots=hwkxuIwBH N\& sig=FQm_6F-9BNi7TUcqnymPswclpGU.

[7] Epstein W. 1977. "Why States Go-And Don't Go-Nuclear." The Annals of American Academy of Political and Social Science 430(1):16-28. Accessed March 24, 2009, at http://ann.sagepub.com/cgi/content/abstract/430/1/16.

[8] Mozley RF. 1998. The Politics and Technology of Nuclear Proliferation. University of Washington Press, Seattle, Washington.

[9] Campbell KM, RJ Einhorn, MB Reiss (ed.). 2004. The Nuclear Tipping Point: Why States Reconsider Their Nuclear Choices. The Brookings Institution, Washington D.C.

[10] Kissinger H. 2009. “Our Nuclear Nightmare.” Newsweek, From February 16, 2009 issue.

[11] International Atomic Energy Agency (IAEA) STR-332. 2002. Proliferation Resistance Fundamentals for Future Nuclear Energy Systems. IAEA, Vienna, Austria.

[12] PNNL-14294. 2003. Guidelines for the Performance of Nonproliferation Assessment. Pacific Northwest National Laboratory, Richland, Washington. 
[13] Cleary VD, PE Rexroth, GE Rochau, DH Saltiel, WS Charlton, DG Ford, and D Giannangeli. 2007. Strengthening the Foundations of Proliferation Assessment Tools. SAND2007-6158, Sandia National Laboratories, Albuquerque, New Mexico.

[14] Generation IV International Forum/Proliferation Resistance and Physical Protection Working Group (GIF/PR\&PPWG). 2006. Revision 5, 2006/005. Evaluation Methodology for Proliferation Resistance and Physical Protection of Generation IV Nuclear Energy Systems. Generation IV International Forum.

[15] IAEA-TECDOC-1434. 2004. Methodology for the Assessment of Innovative Nuclear Reactors and Fuel Cycles. Report of Phase $1 B$ (first part) of the International Project on Innovative Nuclear Reactors and Fuel Cycles (INPRO). International Atomic Energy Agency (IAEA), Vienna, Austria.

\section{From Section 3.1}

[1] Epstein W. 1977. "Why States Go-And Don't Go-Nuclear." The Annals of American Academy of Political and Social Science 430(1):16-28. Accessed March 24, 2009, at http://ann.sagepub.com/cgi/content/abstract/430/1/16.

[2] Meyers S. 1984. The Dynamics of Nuclear Proliferation. The University of Chicago Press, Chicago, Illinois.

[3] Singh S and CR Way. 2004. "The Correlates of Nuclear Proliferation: A Quantitative Test." Journal of Conflict Resolution 48(6):859-885.

[4] Singer JD and M Small. 1982. Resort to Arms: International and Civil Wars, 1816-1980. Sage Publications, Beverly Hills, California.

[5] Correlates of War Project. 2003. State System Membership List, v2002.1. Accessed September 29, 2009, at www.correlatesofwar.org.

[6] Sanger Dd E. "Clinton Says Nuclear Aim of Iran is Fruitless.” New York Times, July 26, 2009. Accessed September 29, 2009, at http://www.nytimes.com/2009/07/27/us/politics/27clinton.html.

[7] Kadera KM, MJC Crescenzi, ML Shannon. 2003. "Democratic Survival, Peace and War in the International System.” American Journal of Political Science. 47(2): 234-247.

[8] Bennet SD. 1998. "Integrating and Testing Models of Rivalry Termination." American Journal of Political Science 42:1200-1232.

[9] Jones DM, SA Bremer, and JD Singer. 1996. . "Militarized Interstate Disputes, 1816-1992: Rationale, Coding Rules, and Empirical Patterns." Conflict Management and Peace Science 15(2):163:213. Accessed September 29, 2009, at www.correlatesofwar.org.

[10] Ikenberry GJ. 1998. "Institutions, Strategic Restraing, and the Persistence of American Postwar Order.” International Security, 23( 3): 43-78.

[11] Henrion, M, JS Breese, and EJ Horvitz. 1991. "Decision Analysis and Expert Systems." AI Magazine 12(4): 64-91.. 
[12] Jenson FV. 1996. An Introduction to Bayesian Networks. Springer, New York.

[13] Roos T, H Wettig, P Grunwald, P Myllymaki, and H Tirri. 2005. “On Discriminative Bayesian Network Classifiers and Logistic Regression.” Machine Learning 59:267-296.

[14] Coombs CH, RM Dawes, and A Tversky. 1970. Mathematical Psychology: An Elementary Introduction. Prentice-Hall, Inc., Englewood Cliffs, New Jersey.

[15] Therios, I. 2006. “ESFR Pyroprocessing Facility Description and Preliminary Safeguards Approach for PR\&PP Demonstration Study." Argonne National Laboratory, University of Chicago, Chicago, Illinois.

[16] Jo, Dong-Joon and Erik Gartzke. "Determinants of Nuclear Weapons Proliferation.” Journal of Conflict Resolution, 2007, Vol 51, No 1, 167-194. DOI: 10.1177/0022002706296158. The dataset is available at http://jcr.sagepub.com/cgi/content/full/f1/1/167/DC1

[17] PNNL-18438. 2009. Utility of Social Modeling for Proliferation Assessment - Preliminary Assessment. Pacific Northwest National Laboratory, Richland, Washington.

[18] Neapolitan RE. 2003. Learning Bayesian Networks. Prentice Hall, Upper Saddle River, New Jersey.

\section{From Section 3.2}

[1] Generation IV International Forum/Proliferation Resistance and Physical Protection Working Group (GIF/PR\&PPWG). 2006. Revision 5, 2006/005. Evaluation Methodology for Proliferation Resistance and Physical Protection of Generation IV Nuclear Energy Systems. Generation IV International Forum.

\section{From Chapter 4}

[1] Pomeroy G, R Bari, E Wonder, M Zentner, E Haas, T Killeen, G Cojazzi, and J Whitlock. 2008. "Approaches to Evaluation of Proliferation Resistance of Nuclear Energy Systems." In: The 49th Annual Meeting: Institute of Nuclear Materials Management, July 13-17, Nashville, Tennessee.

\section{From Chapter 4}

[1] Jo D-J and E Gartzke. 2007. "Determinants of Nuclear Weapons Proliferation." Journal of Conflict Resolution 51(1):167-194. Accessed March 24, 2009, at http://jcr.sagepub.com/cgi/content/abstract/51/1/167.

[2] PNNL-18438. 2009. Utility of Social Modeling for Proliferation Assessment-Preliminary Assessment. Pacific Northwest National Laboratory, Richland, Washington. 



\section{Appendix A}

\section{Definitions}





\section{Appendix A}

\section{Definitions}

Bayesian Network - A graphical probability model that represent a set of variables and their probabilistic independencies. Formally, Bayesian Networks are directed acyclic graphs whose nodes represent variables, and whose missing edges encode conditional independencies between the variables. The word "Bayesian" comes from use of Bayes theorem and is derived from the work of Reverend Thomas Bayes [1].

Dempster-Shafer theory - A mathematical theory of evidence [2] based on "belief functions" and "plausibility reasoning," which is used to combine separate pieces of information (evidence) to calculate the probability of an event. The theory was developed by Arthur P. Demspter and Glenn Shafer.

State-sponsored nuclear proliferation - State sponsorship of material acquisition, processing, and weaponization activities with the intention to develop at least one nuclear weapon.

Proliferation resistance - That characteristic of a nuclear energy system that impedes the diversion or undeclared production of nuclear material or misuse of technology by States to acquire nuclear weapons or other nuclear explosive devices.

Safeguards - As used in the regulation of domestic nuclear facilities and materials, the use of material control and accounting programs verify that all special nuclear material is properly controlled and accounted for, and the physical protection (also referred to as physical security) equipment and security forces.

As used by the International Atomic Energy Agency (IAEA), verifying that the "peaceful use" commitments made in binding nonproliferation agreements, both bilateral and multilateral, are honored. [3].

\section{References}

[1] Hubbard D. 2007. How to Measure Anything: Finding the Value of Intangibles in Business. John Wiley \& Sons, Inc., New York.

[2] Shafer G. 1976. A Mathematical Theory of Evidence. Princeton University Press, Princeton, New Jersey. ISBN 0-608-02508-9.

[3] U.S. Nuclear Regulatory Agency (NRC). 2009. Glossary. Accessed March 24, 2009, at http://www.nrc.gov/reading-rm/basic-ref/glossary/safeguards.html. 



\section{Appendix B}

\section{Expert Questionnaire}





\section{Appendix B}

\section{Expert Questionnaire}

\section{Survey Instructions}

The goal of this research is to determine whether the incorporation of social factors into Proliferation Resistance (PR) assessments-through the augmentation of threat characterizations for proliferation pathway assessments - may alter the technical proliferation measures in those assessments.

In this survey, you will be presented with two proliferation pathways for the PWR-1000: a diversion pathway and a misuse pathway. The pathways were developed as part of the development of the Generation IV International Forum (GIF) PR and Physical Protection (PR\&PP) assessment methodology.

Each of the pathways is presented with three distinct threat characterizations: Case 1, Case 2, and Case 3. Read the proliferation pathway description and threat characterization for Case 1 . Then, score the proliferation pathway according to the measures explained in Table B.1.

Next, examine the threat characterization in Case 2 and, in the space provided, please note how it would have affected your assessment of the pathway measures by indicating how the threat characterization would have changed your score (lower, same, higher) and approximating (quantitatively) how much it would have changed the score compared to the evaluation you did for Case 1. Repeat this process for Case 3, comparing how your results would be different from Case 1. Please explain your answers in the comments section of each row.

After you have completed the your assessments for Case 1,2, and 3 of the first proliferation pathway, assess the second proliferation pathway the same way-first by evaluating the pathway with the Case 1 threat characterization, and then describing how your assessment would change for the Case 2 and 3 threat characterizations. We appreciate your feedback.

Thank you!

Table B.1. Explanation of Measures

\begin{tabular}{ll}
\hline $\begin{array}{l}\text { Proliferation Technical } \\
\text { Difficulty }\end{array}$ & $\begin{array}{l}\text { Probability of pathway failure from inherent difficulty considering threat } \\
\text { capabilities }\end{array}$ \\
$\begin{array}{l}\text { Proliferation Cost } \\
\text { Proliferation Time }\end{array}$ & $\begin{array}{l}\text { Fraction of national resources for military capabilities } \\
\text { Fissile Material Type }\end{array}$ \\
$\begin{array}{l}\text { Detection Probability } \\
\text { Detection Resource Efficiency }\end{array}$ & Probability that safeguards will detect diversion or misuse during the execution \\
\hline
\end{tabular}




\section{PROLIFERATION PATHWAY: PWR-1000 Abrupt Diversion of Fresh Fuel from Storage Area}

Removal of at least 1 SQ of LEU fresh fuel (4 assemblies @ 4.5\% enrichment), from dry storage area in the AUX building near spent fuel pool for dissolution and re-enrichment at an off-site facility.

\section{Actions:}

1. Construct U enrichment plant capable of at least $2500 \mathrm{SWU} / \mathrm{year}$.

2. Fabricate dummy assemblies containing Nat-U. This will involve acquiring $U$ and dummy assembly pre-forms. Replicate serial \#, etc.

3. Bring dummy assemblies to fresh fuel storage, using truck and crane--not forklift.

4. Lift assemblies to divert from storage (with crane or forklift) and replace with dummy assemblies (using crane so as to not damage).

5. Move through truck bay and load, transport off-site with appropriately sized vehicle.

6. Process and enrich at remote facility.

7. Dummy assemblies may or may not be loaded into reactor in future.

Pathway Information:

- MBA: Fresh Fuel Storage

- Exit: Vehicle Access door for fresh fuel delivery (truck bays)

- Target: Fresh Fuel (LEU 5\% enriched)

- Container Type: Suitable container 16 by 4 by 1 feet 3 ton capacity

- Container Location: Entrance to fresh fuel area

- Normal Container Contents: N/A

- Process: Fresh fuel element is transported from fresh fuel storage and loaded onto transport vehicle

- Operational State: N/A

- Safeguards: Material Accountancy (books, NDA, item counting, serial \# ID). Presently, IAEA SGs do not employ Containment \& Surveillance (seals, cameras) in fresh fuel storage area.

Case 1: Please evaluate the pathway above (PWR-1000 Abrupt Diversion of Fresh Fuel from Storage Area) based on the following threat description.

The host State is a Non-Nuclear Weapons State (NNWS) with a national plan to introduce nuclear power in the near term. The State is apparently fully committed to its nonproliferation obligations, is a signatory to the Nuclear Nonproliferation Treaty (NPT) and has the Additional Protocol (AP) in force.

The State has experience in operating several research reactors but not power reactors. It has limited nuclear fuel-cycle capabilities. The State has no declared indigenous enrichment or reprocessing capability but has a limited ability to fabricate fuel, produce isotopes (including chemical separations knowhow and experience), and handle radioactive waste. The State's industrial infrastructure is able to 
support the nuclear industry through development of nuclear technology, provide training for experts in the field, and manufacture basic nuclear equipment components.

A State agency or a nongovernment commercial organization will operate the reactor under the regulatory framework of the host country for safety and security. The State has determined to produce nuclear weapons and intends to acquire at least one SQ of weapons-usable material in 1-10 years.

\begin{tabular}{lrrrrr}
\hline & Very Low & \multicolumn{1}{c}{ Low } & \multicolumn{1}{c}{ Medium } & \multicolumn{1}{c}{ High } & \multicolumn{1}{c}{ Very High } \\
\hline Proliferation Technical Difficulty: & $0-5 \%$ & $5-25 \%$ & $25-75 \%$ & $75-95 \%$ & $95-100 \%$ \\
Proliferation Cost: & $0-5 \%$ & $5-25 \%$ & $25-75 \%$ & $75-100 \%$ & $>100 \%$ \\
Proliferation Time: & $0-3$ months & $3-12$ months & $1-10$ years & $10-30$ years & $>30$ years \\
Fissile Material Type: & HEU & WG-Pu & RG-Pu & DB-Pu & LEU \\
Detection Probability: & $0-5 \%$ & $5-25 \%$ & $25-75 \%$ & $75-95 \%$ & $95-100 \%$ \\
Detection Resource Efficiency: & $<0.01$ & $0.01-0.04$ & $0.04-0.1$ & $0.1-0.3$ & $>0.3$ \\
& GWyear/PDI & GWyear/PDI & GWyear/PDI & GWyear/PDI & GWyear/PDI) \\
\hline
\end{tabular}

Comments:

Case 2: Please indicate how your score would have changed from Case 1 for the pathway above (PWR-1000 Abrupt Diversion of Fresh Fuel from Storage Area) based on the following threat description.

The host State is an NNWS with a national plan to introduce nuclear power in the near term. The State's government system includes the presence of institutions and procedures through which citizens can express effective preferences about alternative policies and leaders, the existence of institutionalized constraints on the exercise of power by the chief? executive, and a guarantee of civil liberties to all citizens in their daily lives and in acts of political participation. The State is apparently fully committed to its nonproliferation obligations, is a signatory to the NPT and has the AP in force. The State has among the highest GDP per capita in the world, as well as one of the largest overall economies in the world. The host State had, on average, at least two militarized international disputes in the past 5 years, and has at least one enduring rivalry.

The State has experience in operating several research reactors but not power reactors. It has limited nuclear fuel-cycle capabilities. The State has no declared indigenous enrichment or reprocessing capability but has a limited ability to fabricate fuel, produce isotopes (including chemical separations knowhow and experience), and handle radioactive waste. The State has high domestic energy, electricity, and steel production on a per-capita and aggregate basis, and represents the most industrially developed countries. The State domestically produces steel and at least $5000 \mathrm{MW}$ of electricity.

A State agency or a nongovernment commercial organization will operate the reactor under the regulatory framework of the host country for safety and security. The State has determined it will produce nuclear weapons and intends to acquire at least one SQ of weapons-usable material in 1-10 years.

\begin{tabular}{llll}
\hline & $\begin{array}{l}\text { Compared } \\
\text { to Case 1 }\end{array}$ & Amount & Comments (Why?) \\
\hline Proliferation Technical Difficulty: & $\begin{array}{l}\text { Higher } \\
\text { No change }\end{array}$ & \\
\hline
\end{tabular}




\begin{tabular}{ll}
\hline \multirow{2}{*}{ Proliferation Cost: } & Lower \\
& Higher \\
& No change \\
Proliferation Time: & Lower \\
& Higher \\
& No change \\
Fissile Material Type: & Lower \\
& Higher \\
& No change \\
Detection Probability: & Lower \\
& Higher \\
& No change \\
Detection Resource Efficiency: & Lower \\
& Higher \\
& No change \\
& Lower \\
\hline
\end{tabular}

Additional Comments:

Case 3: Please indicate how your score would have changed from Case 1 for the pathway above (PWR-1000 Abrupt Diversion of Fresh Fuel from Storage Area) based on the following threat description.

The host State is an NNWS with a national plan to introduce nuclear power in the near term. The State's government system includes a sharp restriction or suppression of competitive political participation, a regularized process of selection within the political elite for chief executives, and the exercise of executive power with few institutionalized constraints. The State is apparently fully committed to its nonproliferation obligations, is a signatory to the NPT, and has the AP in force. The State has among the lowest GDP per capita in the world, and one of the smallest overall economies in the world. The State had no militarized international disputes in the past 5 years, and has no enduring rivalries.

The State does not have previous experience operating a research reactor or power reactors. It has limited nuclear fuel-cycle capabilities. The State has no declared indigenous fuel fabrication, enrichment or reprocessing capability, but has limited capability to produce isotopes (including chemical separations knowhow and experience), and handle radioactive waste. The State has relatively low domestic energy, electricity, and steel production on a per-capita or aggregate basis and represents the least industrially developed countries. The State does not domestically produce steel and produces less than $5000 \mathrm{MW}$ of electricity.

A State agency or a nongovernment commercial organization will operate the reactor under the regulatory framework of the host country for safety and security. The State has determined it will produce nuclear weapons and intends to acquire at least one SQ of weapons-usable material in 1-10 years.

\begin{tabular}{llll}
\hline & $\begin{array}{l}\text { Compared } \\
\text { to Case 1 }\end{array}$ Amount & Comments (Why?) \\
\hline Proliferation Technical Difficulty: & Higher & \\
& No change & \\
& Lower & \\
Proliferation Cost: & Higher & \\
\hline
\end{tabular}




\begin{tabular}{ll}
\hline & No change \\
Proliferation Time: & Lower \\
& Higher \\
& No change \\
Fissile Material Type: & Lower \\
& Higher \\
& No change \\
Detection Probability: & Lower \\
& Higher \\
& No change \\
Detection Resource Efficiency: & Lower \\
& Higher \\
& No change \\
& Lower \\
\hline
\end{tabular}

Additional Comments:

\section{PROLIFERATION PATHWAY: PWR-1000 Undeclared Production of WG-Pu using SBU Fuel (Misuse)}

\section{Abrupt diversion after misuse of reactor to irradiate undeclared fertile material in guide tubes in one cycle.}

Actions:

1. Procure fertile material (e.g. $x$ tons of natural uranium).

2. Manufacture targets.

3. Insert targets into guide tubes (e.g., 27 Westinghouse fresh fuel assemblies, 24 target pins in each).

4. Load modified fuel assemblies in fresh fuel storage.

5. Load modified fuel assemblies in reactor.

6. Operate reactor for one cycle.

7. Remove fuel during outage and put into spent fuel pool.

8. Retrieve irradiated target pins.

9. Load irradiated pins in waste storage basket (could be treated as burnable poison rods).

10. Reprocess.

Pathway Information:

- MBA: Spent fuel pool

- Exit: Cask loading access canal

- Target: SBU fresh fuel

- Container Type: Spent fuel shipping cask 
- Container Location: Cask loading pool

- Normal Container Contents: Normal spent fuel

- Process: Same process as normal spent fuel loading

- Operational State: Normal spent fuel shipping process

- Safeguards: Material Inventory, C/S detectors, crane movement

Case 1: Please evaluate the pathway above (PWR-1000 Undeclared Production of WG-Pu using SBU Fuel [Misuse]) based on the following threat description.

The host State is an NNWS with a national plan to introduce nuclear power in the near term. The State is apparently fully committed to its nonproliferation obligations, is a signatory to the NPT, and has the AP in force.

The State has experience in operating several research reactors but not power reactors. It has limited nuclear fuel-cycle capabilities. The State has no declared indigenous enrichment or reprocessing capability but has a limited ability to fabricate fuel, produce isotopes (including chemical separations knowhow and experience), and handle radioactive waste. The State's industrial infrastructure is able to support the nuclear industry through development of nuclear technology, provide training for experts in the field, and manufacture basic nuclear equipment components.

A State agency or a nongovernment commercial organization will operate the reactor under the regulatory framework of the host country for safety and security. The State has determined to produce nuclear weapons and intends to acquire at least one SQ of weapons-usable material in 1-10 years.

\begin{tabular}{lrrrrr}
\hline & Very Low & \multicolumn{1}{c}{ Low } & \multicolumn{1}{c}{ Medium } & \multicolumn{1}{c}{ High } & \multicolumn{1}{c}{ Very High } \\
\hline Proliferation Technical & $0-5 \%$ & $5-25 \%$ & $25-75 \%$ & $75-95 \%$ & $95-100 \%$ \\
Difficulty: & & & & & \\
Proliferation Cost: & $0-5 \%$ & $5-25 \%$ & $25-75 \%$ & $75-100 \%$ & $>100 \%$ \\
Proliferation Time: & $0-3$ months & $3-12$ months & $1-10$ years & $10-30$ years & $>30$ years \\
Fissile Material Type: & HEU & WG-Pu & RG-Pu & DB-Pu & LEU \\
Detection Probability: & $0-5 \%$ & $5-25 \%$ & $25-75 \%$ & $75-95 \%$ & $95-100 \%$ \\
Detection Resource & $<0.01$ & $0.01-0.04$ & $0.04-0.1$ & $0.1-0.3$ & $>0.3$ \\
Efficiency: & GWyear/PDI & GWyear/PDI & GWyear/PDI & GWyear/PDI & GWyear/PDI) \\
\hline
\end{tabular}

Comments:

Case 2: Please indicate how your score would have changed from Case 1 for the pathway above (PWR-1000 Undeclared Production of WG-Pu using SBU Fuel [Misuse]) based on the following threat description. 
The host State is an NNWS with a national plan to introduce nuclear power in the near term. The State's government system includes the presence of institutions and procedures through which citizens can express effective preferences about alternative policies and leaders, the existence of institutionalized constraints on the exercise of power by the chief? executive, and a guarantee of civil liberties to all citizens in their daily lives and in acts of political participation. The State is apparently fully committed to its nonproliferation obligations, is a signatory to the NPT, and has the AP in force. The State has among the highest GDP per capita in the world, as well as one of the largest overall economies in the world. The host State had, on average, at least two militarized international disputes in the past 5 years, and has at least one enduring rivalry.

The State has experience in operating several research reactors but not power reactors. It has limited nuclear fuel-cycle capabilities. The State has no declared indigenous enrichment or reprocessing capability but has a limited ability to fabricate fuel, produce isotopes (including chemical separations knowhow and experience), and handle radioactive waste. The State has high domestic energy, electricity, and steel production on a per-capita and aggregate basis, and represents the most industrially developed countries. The State domestically produces steel and at least $5000 \mathrm{MW}$ of electricity.

A State agency or a nongovernment commercial organization will operate the reactor under the regulatory framework of the host country for safety and security. The State has determined it will produce nuclear weapons and intends to acquire at least one SQ of weapons-usable material in 1-10 years.

\begin{tabular}{ll}
\hline & $\begin{array}{l}\text { Compared } \\
\text { to Case 1 Amount }\end{array}$ \\
\hline Proliferation Technical Difficulty: & Higher \\
& No change \\
& Lower \\
Proliferation Cost: & No change \\
& Lower \\
Proliferation Time: & Higher \\
& No change \\
Fissile Material Type: & Lower \\
& Higher \\
& No change \\
Detection Probability: & Lower \\
& Higher \\
& No change \\
Detection Resource Efficiency: & Lower \\
& Higher \\
& No change \\
& Lower \\
\hline Additional Comments: & \\
& \\
\hline
\end{tabular}

Case 3: Please indicate how your score would have changed from Case 1 for the pathway above (PWR-1000 Undeclared Production of WG-Pu using SBU Fuel [Misuse]) based on the following threat description.

The host State is an NNWS with a national plan to introduce nuclear power in the near term. The State's government system includes a sharp restriction or suppression of competitive political 
participation, a regularized process of selection within the political elite for chief executives, and the exercise of executive power with few institutionalized constraints. The State is apparently fully committed to its nonproliferation obligations, is a signatory to the NPT and has the AP in force. The State has among the lowest GDP per capita in the world, and one of the smallest overall economies in the world. The State had no militarized international disputes in the past 5 years, and has no enduring rivalries.

The State does not have previous experience operating a research reactor or power reactors. It has limited nuclear fuel-cycle capabilities. The State has no declared indigenous fuel fabrication, enrichment or reprocessing capability, but has limited capability to produce isotopes (including chemical separations knowhow and experience), and handle radioactive waste. The State has relatively low domestic energy, electricity, and steel production on a per-capita or aggregate basis and represents the least industrially developed countries. The State does not domestically produce steel and produces less than $5000 \mathrm{MW}$ of electricity.

A State agency or a nongovernment commercial organization will operate the reactor under the regulatory framework of the host country for safety and security. The State has determined it will produce nuclear weapons and intends to acquire at least one SQ of weapons-usable material in 1-10 years.

\begin{tabular}{lll}
\hline & $\begin{array}{l}\text { Compared } \\
\text { to Case 1 Amount }\end{array}$ Comments (Why?) \\
\hline Proliferation Technical Difficulty: & Higher \\
& No change \\
& Lower \\
Proliferation Cost: & Higher \\
& No change \\
& Lower \\
Proliferation Time: & Higher \\
& No change \\
Fissile Material Type: & Lower \\
& Higher \\
& No change \\
Detection Probability: & Lower \\
& Higher \\
& No change \\
Detection Resource Efficiency: & Lower \\
& Higher \\
& No change \\
& Lower \\
\hline
\end{tabular}

Additional Comments: 



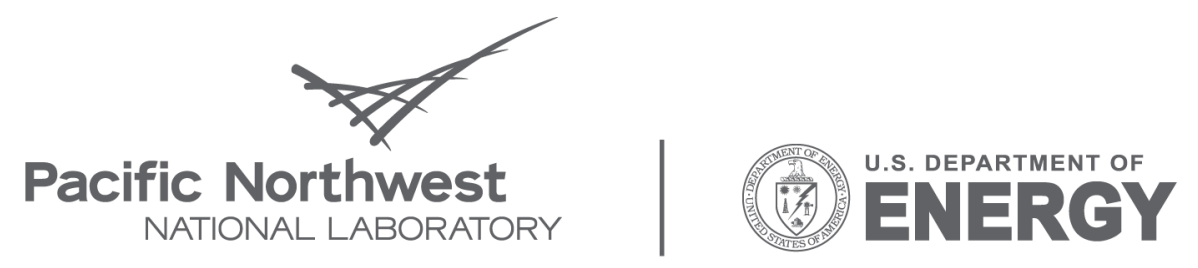

Proudly Operated by Battelle Since 1965

902 Battelle Boulevard

P.O. Box 999

Richland, WA 99352

1-888-375-PNNL (7665)

www.pnl.gov 